\title{
24. CRETACEOUS-PALEOCENE PALYNOLOGY FROM THE CÔTE D'IVOIRE-GHANA TRANSFORM MARGIN, SITES 959, 960, 961, AND 962 ${ }^{1}$
}

\author{
E. Masure, ${ }^{2}$ R. Rauscher, ${ }^{3}$ J. Dejax, ${ }^{4}$ M. Schuler, ${ }^{3}$ and B. Ferré ${ }^{5}$
}

\begin{abstract}
A set of 204 Cretaceous and Paleocene samples from Holes 959D, 960A, 960C, 961A, 961B, 962B, 962C (barren), and 962D of the Côte d'Ivoire-Ghana Transform Margin (Leg 159) were palynologically analyzed. Three main types of palynofacies were distinguished. The first type indicates strong terrestrial depositional conditions and characterizes lithologic Unit $\mathrm{V}$ of Hole 959D, Subunit VB and most samples of Subunit VA of Hole 960A, and Unit III of Holes 961A and 961B. The presence of some stratigraphically significant spores and pollen grains indicates a late Barremian-middle Albian age for Unit $\mathrm{V}$ of Holes 959D and 960A, and a middle Albian age for Unit III of Holes 961 A and 961B. The second type of palynofacies reveals mixed terrestrial and marine depositional conditions. This type was observed in Subunit IIC of Hole 962B and Unit III of Hole 962D. The occurrence of stratigraphically significant spore, pollen grain, and dinoflagellate cyst species argues for a Cenomanian age for these units in Holes 962B and 962C. The third type of palynofacies indicates clearly marine environmental conditions. This type is found in Subunit IVA and Unit III of Hole 959D, where highly diversified dinocyst assemblages (73 species, among them the following three new ones: Spiniferites bejuii n. sp., Spiniferites sp. G, and Xenascus ghanaensis n. sp.) were identified. Based on the presence of several Late Cretaceous and Paleocene markers, precise age determinations are possible for this part of Hole 959D: Subunit IVA and the lowermost cores of Unit III are probably early Coniacian in age; subsequent cores of Unit III are Santonian, Campanian, Maastrichtian, Danian and, at the top, late Thanetian in age.
\end{abstract}

\section{INTRODUCTION}

Ocean Drilling Program (ODP) Leg 159 was devoted to the analysis of the Côte d'Ivoire-Ghana Transform Margin located in the eastern equatorial Atlantic Ocean (Fig. 1). The main evolutionary phases of such a transform margin were described by Mascle and Blarez (1987), Basile et al. (1992, 1993), and Mascle, Lohmann, Clift, et al. (1996). Dating of the events that participated in the margin's construction requires accurate stratigraphic studies of the cored sediments. Preliminary biostratigraphic results, mainly by the identification of calcareous nannofossils, planktonic foraminifers, and radiolarians and secondarily by silicoflagellates and palynology, indicate that the transform margin sediment covers an age ranging from the late Albian to the Pleistocene. Our palynological analyses are particularly concerned with the lowermost deposits (Cretaceous and Paleocene) of the transform margin. This study had two main purposes: (1) to date by palynomorphs (dinoflagellate cysts, spores, and pollen grains) the first events that marked the transform margin construction, and (2) to specify some environmental characteristics (terrestrial and/or marine influences; thermal alteration) of the first stages of margin evolution.

\section{MATERIALS AND METHODS}

Four distinct sites were drilled during Leg 159 (Fig. 1). Results were published in the Leg 159 Initial Reports volume (Mascle, Lohmann, Clift, et al., 1996).

${ }^{1}$ Mascle, J., Lohmann, G.P., and Moullade, M. (Eds.), 1998. Proc. ODP, Sci. Results, 159: College Station, TX (Ocean Drilling Program).

2Département de Géologie Sédimentaire, Laboratoire de Micropaléontologie, URA CNRS 1761, Université P. et M. Curie, case 104, 4 place Jussieu, 75252 Paris Cedex 05, France.edmasure@ccr.jussieu.fr

${ }^{3}$ Centre de Géochimie de la Surface (CNRS), 1 rue Blessig, 67084 Strasbourg Cedex, France.

${ }^{4}$ Laboratoire de Paléontologie, Museum National d'Histoire Naturelle, 8 rue Buffon, 75005 Paris, France.

${ }_{5}^{5}$ Laboratoire de Géologie, Université d'Angers, 2 boulevard Lavoisier, 49045 Angers Cedex, France.
Site 959 is located on the southern edge of the Deep Ivorian Basin, just north of the top of the Côte d'Ivoire-Ghana marginal ridge. Four holes (959A-959D) were drilled. Only Hole 959D was sampled for palynological analyses. This hole is subdivided into five lithologic units. Our study concerns, from bottom to top, Unit V (interval 159959D-78R-CC, $20 \mathrm{~cm}$, to 71R-1, $0 \mathrm{~cm}$ ), which is dominated by sandstones embedded with fine-grained clay-rich sediments considered to be late Albian in age; Subunit IVB (interval 159-959D-70R-1, $43 \mathrm{~cm}$, to 69R-1, $0 \mathrm{~cm}$ ), consisting of limestone and dolomitic limestone of unknown age (no sample from this interval was analyzed); Subunit IVA (interval 159-959D-68R-CC, $15 \mathrm{~cm}$, to 67R-1, $0 \mathrm{~cm}$ ) consisting of beds of sandy dolomite and sandy limestone and calcareous sandstone, early Turonian to early Coniacian in age; and Unit III (interval 159-959D-66R-CC, $38 \mathrm{~cm}$, to 43R-1, $0 \mathrm{~cm}$ ), consisting of black claystones and dated from early Coniacian to late Paleocene, with intermediate stage boundaries unknown. Biostratigraphic control was provided by shipboard analyses of calcareous nannoplankton, planktonic foraminifers, silicoflagellates, and palynomorphs (Shipboard Scientific Party, 1996a). According to the Shipboard Scientific Party, hiatuses may be present in the Cretaceous, and a hiatus is probably also present in the Paleocene (Danian).

Site 960 is located $3 \mathrm{mi}$ south of Site 959 , near the summit of the Côte d'Ivoire-Ghana marginal ridge. Two holes, Holes 960A and 960C, were palynologically analyzed. In Hole 960A, our samples came from lithologic Subunit VB (interval 159-960A-61R-CC, $4 \mathrm{~cm}$, to $54 \mathrm{R}-1,0 \mathrm{~cm}$ ), which is comprised of a succession of silty sandstone, sandy siltstone, clayey siltstone, and silty claystone, and from Subunit VA (interval 159-960A-53R-CC, $23 \mathrm{~cm}$, to 37R-1, $45 \mathrm{~cm}$ ), characterized by claystone and sandstone. The ages of these units is unknown. In Hole 960C, only two samples were analyzed. They were taken from Subunit IVB (interval 159-960C-26X-CC, $23 \mathrm{~cm}$, to 24X$1,0 \mathrm{~cm})$, which is Turonian to Coniacian in age.

Site 961 is located on the last significant morphologic expression of the Côte d'Ivoire-Ghana marginal ridge just before its burial, toward the west. Holes 961A and 961B were analyzed. Samples were from lithologic Unit III (interval 159-961A-35R-CC, $45 \mathrm{~cm}$, to 21R$2,34 \mathrm{~cm}$, and $159-961 \mathrm{~B}-20 \mathrm{R}-\mathrm{CC}, 26 \mathrm{~cm}$, to $1 \mathrm{R}-1,0 \mathrm{~cm}$ ), which is entirely siliciclastic. The age of this interval is uncertain (Bajocian to Maastrichtian). 
Figure 1. Location of Sites 959, 960, 961, and 962 in the Côte d'Ivoire-Ghana Transform Margin area. Bathymetry in meters.

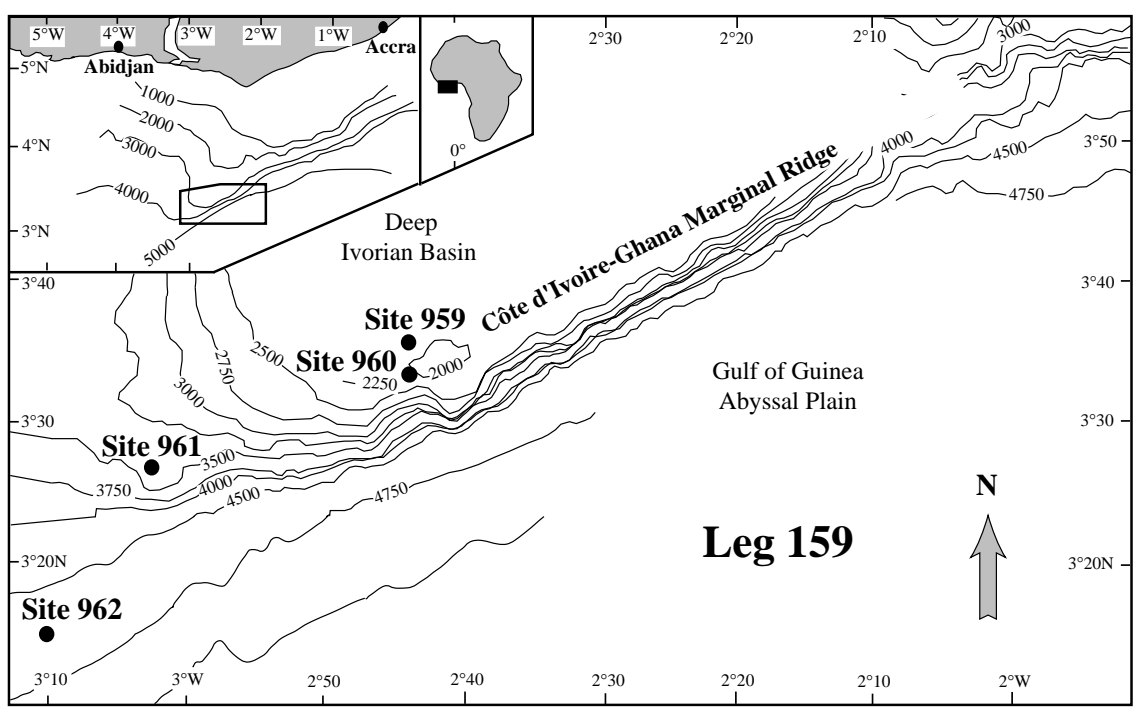

Table 1. Total organic matter content of samples, Hole 959D.

\begin{tabular}{lrl}
\hline $\begin{array}{c}\text { Core, section, } \\
\text { interval }(\mathrm{cm})\end{array}$ & $\begin{array}{c}\text { Depth } \\
(\mathrm{mbsf})\end{array}$ & $\begin{array}{c}\text { TOM } \\
(\mathrm{mL} / 10 \mathrm{~mL} \text { sample })\end{array}$ \\
\hline 159-959D- & & \\
44R-6, 83-85 & 828.93 & 0.25 \\
45R-1, 11-16 & 831.71 & 0.40 \\
46R-1, 95-100 & 842.25 & 0.40 \\
47R-1, 79-82 & 851.69 & 0.83 \\
48R-1, 8-11 & 860.68 & 1.50 \\
49R-1, 139-142 & 871.59 & 0.75 \\
50R-6, 2-5 & 886.92 & 1.67 \\
51R-3, 10-13 & 892.30 & 1.00 \\
52R-3, 129-132 & 903.09 & 1.39 \\
53R-3, 68-71 & 910.97 & 1.50 \\
54R-2, 1-3 & 919.61 & 1.20 \\
55R-4, 94-97 & 932.00 & 1.80 \\
56R-1, 101-103 & 938.41 & 2.20 \\
57R-1, 131-134 & 948.41 & 1.75 \\
58R-3, 123-126 & 960.33 & 1.80 \\
59R-4, 118-123 & 972.18 & 1.50 \\
60R-2, 8-11 & 977.68 & 1.25 \\
60R-4, 16-19 & 980.76 & 1.00 \\
62R-3, 65-70 & 999.05 & 2.00 \\
63R-2, 89-91 & 1007.39 & 1.40 \\
64R-4, 89-92 & 1020.09 & 1.80 \\
65R-4, 8-11 & 1028.68 & 4.40 \\
66R-1, 33-37 & 1034.03 & 4.40 \\
67R-2, 91-95 & 1045.71 & 1.90 \\
72R-2, 85-90 & 1093.55 & 2.50 \\
75R-1, 20-24 & 1120.40 & 1.70 \\
76R-2, 13-16 & 1131.43 & 1.50 \\
\hline & & \\
\hline & & \\
\hline
\end{tabular}

Note: $\mathrm{TOM}=$ total organic matter.

according to its stratigraphical span. Indeed, this phytogeographical zone is characterized by the presence of elater-bearing species and related forms, a variety of polyplicate species, an often high frequency of Afropollis, a high morphological diversification of the angiospermous pollen grains, the absence (or very low occurrence) of mono- to trisaccate gymnospermous pollen grains, and, finally, the scarcity of fern spores. The elater-bearing species and related forms are qualitatively and quantitatively well represented in the axial zone, which extends from northeastern Brazil to West Africa and is close to the paleoequator. The Leg 159 sites are located in this axial zone and the above quoted feature is the case among the palynological assemblages from Holes 961A, 961B, and 962D. The two other provinces that overlap more or less partially the same span of time are the "Early Cretaceous Cerebropollenites Province" and the "Early CretaceousCenomanian Trisaccates Province," whose characteristics are very different. The "Albian-Cenomanian Elaterates Province" is the continuation of the "Pre-Albian West Early Cretaceous Dicheiropollis etruscus/Afropollis Province" defined by the same authors, in which 
Table 2. Total organic matter content of samples, Holes 960A and 960C.

\begin{tabular}{lcc}
\hline $\begin{array}{c}\text { Core, section, } \\
\text { interval }(\mathrm{cm})\end{array}$ & $\begin{array}{c}\text { Depth } \\
(\mathrm{mbsf})\end{array}$ & $\begin{array}{c}\text { TOM } \\
(\mathrm{mL} / 10 \mathrm{~mL} \text { sample })\end{array}$ \\
\hline 159-960A- & & \\
38R-2, 139-142 & 341.09 & 0.80 \\
40R-2, 44-47 & 350.24 & 1.20 \\
41R-2, 9-12 & 352.59 & 1.40 \\
42R-1, 137-140 & 354.87 & 1.00 \\
43R-1, 55-59 & 358.05 & 1.00 \\
45R-1, 4-7 & 367.24 & 0.60 \\
45R-3, 20-24 & 370.40 & 0.60 \\
47R-2, 25-29 & 378.55 & 0.60 \\
47R-CC, 3-8 & 379.21 & 0.60 \\
50R-3, 110-114 & 395.20 & 1.60 \\
53R-1, 90-93 & 404.20 & 2.40 \\
56R-1, 102-106 & 423.82 & 0.80 \\
57R-1, 47-51 & 427.87 & 0.40 \\
58R-1, 104-107 & 433.44 & 1.40 \\
59R-2, 129-133 & 439.55 & 1.00 \\
159-960C- & & \\
26X-2, 44-49 & 345.14 & 4.80 \\
\hline
\end{tabular}

Note: $\mathrm{TOM}=$ total organic matter.

Table 3. Total organic matter content of samples, Holes 961A and 961B.

\begin{tabular}{lll}
\hline $\begin{array}{c}\text { Core, section, } \\
\text { interval }(\mathrm{cm})\end{array}$ & $\begin{array}{c}\text { Depth } \\
\text { (mbsf) }\end{array}$ & $\begin{array}{c}\text { TOM (mL/10 mL } \\
\text { sample) }\end{array}$ \\
\hline 159-961A- & & \\
22R-2, 17-20 & 198.07 & 0.20 \\
23R-1, 60-64 & 206.70 & 0.40 \\
24R-1, 110-113 & 216.80 & 0.40 \\
25R-2, 8-11 & 227.08 & 0.40 \\
26R-1, 13-15 & 235.73 & 0.50 \\
28R-1, 1-3 & 255.31 & 0.50 \\
29R-2, 52-56 & 266.92 & 0.40 \\
30R-2, 36-40 & 276.36 & 0.32 \\
31R-1,34-38 & 284.54 & 0.40 \\
32R-1,96-99 & 294.76 & 0.40 \\
34R-2, 82-87 & 305.82 & 0.40 \\
35R-1, 3-6 & 308.23 & 0.40 \\
159-961B- & & \\
2R-1, 120-123 & 227.20 & 0.40 \\
3R-1, 100-103 & 237.00 & 0.40 \\
4R-2, 100-104 & 262.40 & 0.40 \\
6R-2, 112-115 & 277.12 & 0.20 \\
7R-2, 29-31 & 285.99 & 0.25 \\
8R-2, 25-28 & 295.55 & 0.20 \\
9R-1, 15-18 & 303.65 & 0.40 \\
10R-3, 117-122 & 317.37 & 0.40 \\
11R-1,9-12 & 317.49 & 0.40 \\
12R-1, 87-90 & 323.27 & 0.40 \\
13R-CC,9-12 & 335.30 & 0.38 \\
15R-1, 57-59 & 351.97 & 0.30 \\
16R-2, 117-120 & 358.37 & 0.30 \\
17R-1, 12-16 & 360.82 & 0.30 \\
\hline
\end{tabular}

Note: $\mathrm{TOM}=$ total organic matter.

some genera as Afropollis took root. The characteristics of this older province are strongly peculiar and reveal a different flora, through the predominance of gymnospermous pollen such as Classopollis, the average occurrence of spores, and the appearance of angiospermous pollen.

\section{Hole 959D}

The distribution of the 73 dinoflagellate cyst taxa identified in Hole 959D is given in Figure 2. Full citations for all taxa are given in the "Taxonomy" section below. No figure is given for rare spores and pollen grains.

Unit V(Interval 159-959D-78R-CC, $20 \mathrm{~cm}$, to 71R-1, $0 \mathrm{~cm}$ )

\section{Dinoflagellate Cysts}

The six samples located in Unit V are devoid of dinoflagellate cysts.
Table 4. Total organic matter content of samples, Holes 962B and 962D.

\begin{tabular}{lcc}
\hline $\begin{array}{c}\text { Core, section, } \\
\text { interval }(\mathrm{cm})\end{array}$ & $\begin{array}{c}\text { Depth } \\
\text { (mbsf) }\end{array}$ & $\begin{array}{c}\text { TOM } \\
(\mathrm{mL} / 10 \mathrm{~mL} \text { sample })\end{array}$ \\
\hline 159-962B- & & \\
8H-5, 44-49 & 70.94 & 0.17 \\
9H-4, 65-70 & 79.15 & 1.50 \\
159-962D- & & \\
9R-5, 95-99 & 159.35 & 3.40 \\
10R-2, 74-77 & 164.24 & 2.40 \\
12R-5, 68-71 & 187.98 & 2.40 \\
13R-2, 78-82 & 193.28 & 4.00 \\
16R-3, 95-98 & 223.95 & 1.50 \\
18R-2, 66-70 & 241.26 & 0.40 \\
19R-2, 39-42 & 250.69 & 1.00 \\
20R-3, 8-14 & 261.48 & 1.00 \\
21R-2, 3-6 & 269.35 & 2.00 \\
23R-1, 50-53 & 287.80 & 1.75 \\
24R-2, 119-123 & 299.69 & 1.25 \\
25R-1, 33-37 & 302.33 & 0.80 \\
26R-2, 120-124 & 309.30 & 1.60 \\
27R-1, 40-44 & 311.70 & 1.00 \\
28R-1, 8-10 & 316.38 & 1.00 \\
29R-2, 37-40 & 327.87 & 2.33 \\
30R-1, 40-42 & 336.00 & 0.67 \\
31R-2, 28-31 & 347.08 & 0.75 \\
33R-CC, 0-3 & 366.83 & 1.00 \\
34R-2, 70-73 & 371.50 & 2.00 \\
35R-1, 134-137 & 375.64 & 1.20 \\
36R-2, 19-22 & 385.59 & 3.20 \\
37R-4, 49-52 & 393.49 & 1.60 \\
\hline
\end{tabular}

Note: $\mathrm{TOM}=$ total organic matter.

Spores and Pollen Grains

The lowermost samples in Cores 159-959D-76R and 75R are almost barren. Only some rare Classopollis sp. and one specimen of Cicatricosisporites sp. were identified. Precise age determinations cannot be inferred from such long-ranging forms. Samples in Core 159-959D-72R yielded poorly to moderately preserved spore and pollen assemblages, essentially characterized by Afropollis Doyle et al. (1982). This genus is an important guide-form, particularly for two of the above-quoted provinces, where its geographical and stratigraphical distribution has been mostly defined as the "Pre-AlbianEarly Cretaceous Dicheiropollis etruscus/Afropollis Province" and the "Albian-Cenomanian Elaterates Province." Afropollis appeared in the former, during the late Barremian-early Aptian, close to the Barremian-Aptian boundary (around the transition between zones $\mathrm{C}$ VI and C VII of Société Nationale Elf-Aquitaine [Production]), more or less simultaneously in West Africa (Doyle et al., 1982) and Brazil (Regali, 1987); the genus disappeared during the (middle?) Cenomanian (Doyle et al., 1982). The scarcity and rather bad preservation of these Afropollis grains forbid their assignment at the specific level, hence do not allow us to determine a more accurate age within this stratigraphical range; nevertheless, the absence of some other guide forms, which "usually" co-exist with Afropollis from the middle Albian forward, suggests that lithologic Unit V probably ranges between the late Barremian and middle Albian (all the more that these guide forms, which are-among others-the elater-bearing spores and related forms, occur together with Afropollis elsewhere at other sites of Leg 159, under a presumably rather similar palaeoenvironment).

Unit IV (Interval 159-959D-70R-1, $43 \mathrm{~cm}$, to 67R-1, $0 \mathrm{~cm}$ )

\section{Subunit IVB}

(Interval 159-959D-70R-1, $43 \mathrm{~cm}$, to 69R-1, $0 \mathrm{~cm}$ ); no sample from this interval was analyzed.

\section{Subunit IVA}

(Interval 159-959D-68R-CC, $15 \mathrm{~cm}$, to 67R-1, $0 \mathrm{~cm}$ ). Two samples were studied. 


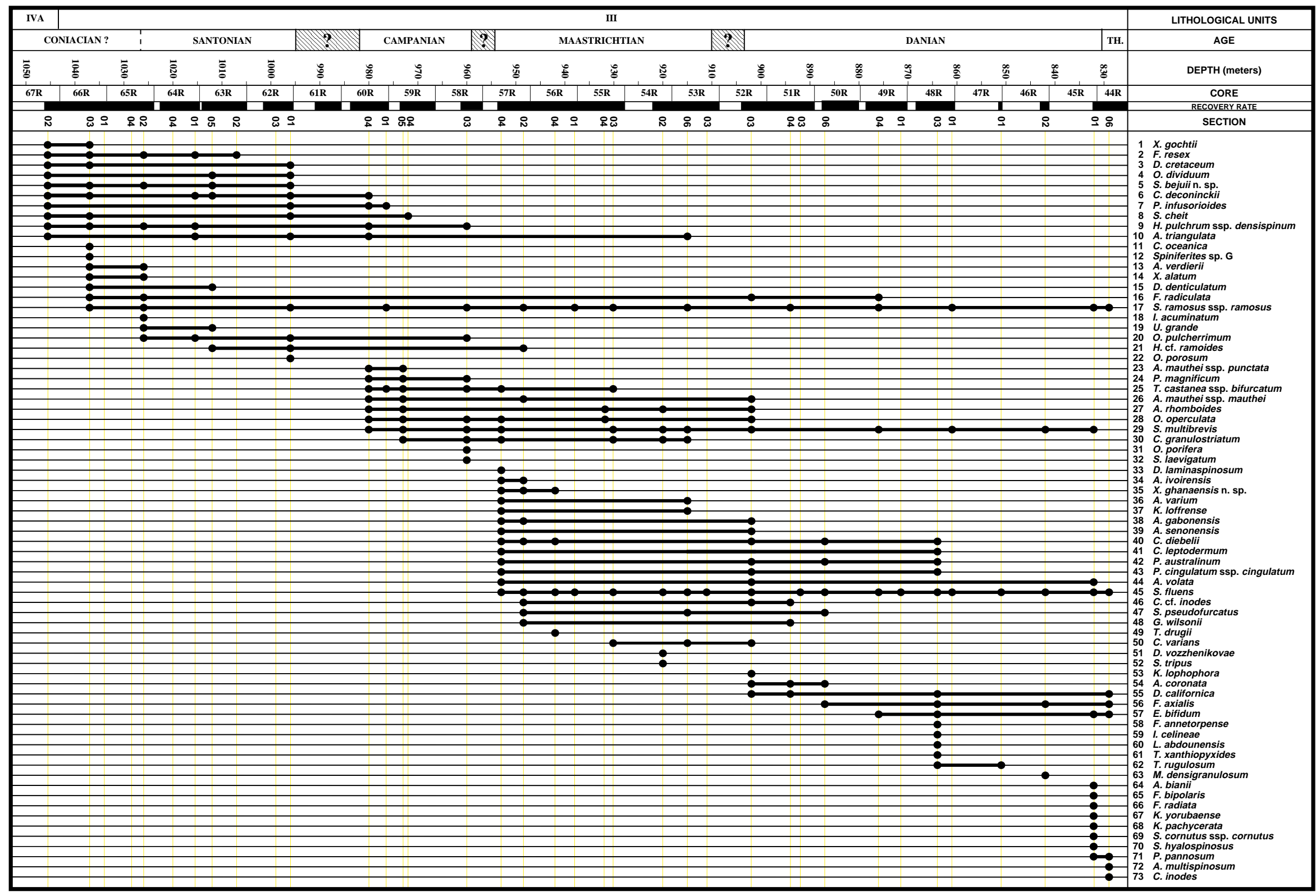




\section{Dinoflagellate Cysts}

The first occurrence of dinoflagellate cyst association is located in Sample 159-959D-67R-2, 57-61 cm. The 10 species (Fig. 2) give some evidence for Senonian age determination. Xenascus gochtii is known to appear during Senonian (Corradini, 1973), more precisely, according to Kirsch (1991), Coniacian-Santonian times. The basal occurrences of other species are located earlier, in the late Albian (Palaeohystrichophora infusorioides) or late Cenomanian-early Turonian (Dinogymnium Group) and are not significant. A Coniacian age is tentatively proposed for Subunit IVA.

\section{Spores and Pollen Grains}

In samples of Core 159-959D-67R, the first dinoflagellate cysts are associated with spores and pollen grains such as Ephedripites zaklinskaiae and Gemmatricolpites chmurae. E. zaklinskaiae was first described from Albian to Turonian deposits of Gabon (Azéma and Boltenhagen, 1974), and G. (= Ilexpollenites) chmurae from early Senonian sediments of Gabon (Boltenhagen, 1976). Recently, Schrank and Ibrahim (1995) observed similar smaller forms, which they described as G. cf. chmurae in middle Cenomanian to lower Turonian well samples from Egypt. Palynological observations could thus slightly lower the preliminary age determinations of Subunit IVA, extending it downwards (middle Cenomanian to early Coniacian).

Unit III (Interval 159-959D-66R-CC, $38 \mathrm{~cm}$, to 43R-1, $0 \mathrm{~cm}$ )

Forty-eight samples were collected from Unit III.

\section{Dinoflagellate Cysts}

This interval contains well-preserved dinoflagellate assemblages composed of 73 species, some of which are stratigraphically significant.

Isabelidinium acuminatum, Sample 159-959D-65R-2, 27-30 cm, is used to tentatively suggest a Santonian age on the basis of its worldwide range chart (Williams and Bujak, 1985, p. 901, fig. 19, number 214). The first occurrence of Unipontidinium grande is located in Section 159-959D-65R-2. The age of U. grande was previously given as probably Campanian (Davey, 1975). Offshore Côte d'Ivoire and Ghana, $U$. grande seems to be restricted to the Santonian.

Members of the Andalusiella group and Trichodinium castanea ssp. bifidum appear in Section 159-959D-60R-4. The first occurrence of these taxa suggests a Campanian age. The Andalusiella Group is recorded from the Campanian of Gabon (Boltenhagen, 1977, pp. 106-111 as the Svalbardella Group) and Egypt (Schrank, 1987). Trichodinium castanea ssp. bifidum, originally described by Jain and Millepied (1975, p. 140), from Maastrichtian sediments of Senegal, is present as early as Campanian in Egypt (Schrank, 1987), and in Hole 959D. The most conspicuous element of Sections 159-959D60R-4 through 58R-3 is formed by very diversified peridinioid species such as Andalusiella spp, Cerodinium granulostriatum, Phelodinium magnificum, and Senegalinium laevigatum. The first appearence datum (FAD) of Phelodinium magnificum is Campanian in the world range charts of Williams and Bujak (1985, p. 901, fig. 19, number 221) and late Campanian (see Kirsch, 1991, p. 141) in the northern Alpine area.

Cerodinium diebelii, Cerodinium leptodermum, Andalusiella ivoirensis, and Alterbidinium varium appear in Section 159-959D-57R4. These significant species argue for a Maastrichtian age. In the stratotype of the Campanian (France), E. Masure (unpubl. data) did not observe Cerodinium diebelii. May (1980) and Kirsch (1991) recognize this species in the Maastrichtian (Navesink Formation, New Jersey, U.S.A. and Upper Bavaria area, respectively), although the FAD of Cerodinium diebelii is late Campanian (Williams and Bujak, 1985, p. 901, fig. 19, number 225). Andalusiella ivoirensis was described from the Maastrichtian of the Ivory Coast (Masure et al., 1996). The first occurrence of Alterbidinium varium is in the early Maastrichtian (Kirsch, 1991; Slimani, 1995). Boltenhagen (1977) mentioned $C$. leptodermum from the late Campanian of Gabon with the Areoligera and Glaphyrocysta groups. The FAD of the Areoligera and Glaphyrocysta groups in the Campanian stratotype is also located in the upper part of the Campanian (E. Masure, unpubl. data). Abundant first appearances of species in Section 159-959D-57R-4 associated with the Areoligera and Glaphyrocysta groups may indicate a condensation horizon or hiatus in the late Campanian.

Danea californica is a significant species of the Danian age (Williams and Bujak, 1985; Powell, 1992). Its first occurrence is located in Sample 159-959D-52R-3, 10-13 cm. D. californica has also been reported from the Danian of Tunisia (Brinkhuis and Zachariasse, 1988). Impagidinium celineae, Sample 159-959D-48R-3, 65-68 cm, and Kallosphaeridium yorubaensee, Sample 159-959D-45R-1, 34$39 \mathrm{~cm}$, have previously been described from the Danian of Nigeria (Jan du Chêne; 1988, Jan du Chêne and Adediran, 1985). A Danian age is suggested for the interval from Section 159-959D-52R-3 through Section 45R-1.

Adnatosphaeridium multispinosum is located in Sample 159959D-44R-6, 60-62 cm. In northwest Europe, the FAD of A. multispinosum characterizes the early Eocene (Ypresian) (Williams and Bujak, 1985, fig. 19, number 285; Powell, 1992, fig. 4.6). Jan du Chêne and Adediran (1985) recorded A. multispinosum associated with Apectodinium groups from the Paleogene of Nigeria. According to the occurrence of A. multispinosum and the missing of Apectodinium group and Eocene species, a late Thanetian age is suggested for Sample 159-959D-44R-6, 60-62 cm.

Spores and Pollen Grains

Very rare and stratigraphically insignificant spores and pollen grains were observed in the interval.

\section{Hole 960A}

We analyzed 35 samples from Section 159-960A-61R-1 through 38R-2, which contains Subunits VB and VA.

\section{Dinoflagellate Cysts}

Samples are devoid of dinoflagellate cysts, except rare, insignificant, or undeterminable specimens.

\section{Spores and Pollen Grains}

Spore and pollen assemblages are almost the same from bottom to top and are always characterized by Afropollis sp. The occurrence of this marker leads to the same age assignment as Unit V in Hole 959D: late Barremian to middle Albian.

\section{Hole 960C}

Only two samples from Cores $159-960 \mathrm{C}-26 \mathrm{X}$ and $24 \mathrm{X}$ were palynologically analyzed. They belong to Subunit IVB, which is Turonian to Coniacian in age (Shipboard Scientific Party, 1996b). Palynological assemblages contain very sparse but well-preserved palynomorphs, one specimen of Dinogymnium sp. (late Cenomanian-late Maastrichtian), and some long-ranging sporomorphs. The specimens of Dinogymnium are very rare in the Lower Cretaceous (Londeix et al. 1996), but abundant during the Late Cretaceous. So a Late Cretaceous (late Cenomanian-late Maastrichtian) age is suggested for the two samples analyzed.

\section{Holes $961 A$ and $961 B$}

Twenty-four samples from Holes 961A (Core 159-961A-35R through 22R) and 29 from Hole 961B (Core 159-961B-17R through $2 \mathrm{R}$ ), both of Unit III are of uncertain age (Bajocian to Maastrichtian, Shipboard Scientific Party, 1996c). 
Dinoflagellate Cysts

The 53 samples studied are barren of dinocysts.

\section{Spores and Pollen Grains}

No significant changes occur among the palynological assemblages of Holes 961A and 961B. They are similar and characterized by the combined occurrence of Afropollis sp. and Classopollis sp. ("smaller than 30 microns," according to Herngreen, 1973, 1975; Herngreen and Chlonova, 1981), rather abundant representatives of the elater-bearing spores Elaterosporites klaszi, E. protensus and E. verrucatus, and especially Reyrea polymorphus, cf. Reyrea, which is, however, quite rare. There is no occurrence of Classopollis larger than $30 \mu \mathrm{m}$ (which belongs mainly to $C$. brasiliensis, according to these authors), nor of the other guide forms. The three elater-bearing species quoted above reach their maximum frequency along the middle to late Albian in the Ivory Coast (Jardiné, 1967). A deduction about the age of Unit III may be drawn from these observations: the palynological characteristics of Unit III fit with pollen Zone I of Herngreen (1973), later called Reyrea polymorphus Zone I by Herngreen (1975), and lead to the Elaterosporites protensus and E. verrucatus Subzone IB, as defined in the latter paper in the Barreirinhas basin of Brazil. Subzone IB ranges through the middle Albian.

\section{Hole $962 B$}

Four samples were analyzed from Subunit IIC (late Albian to Cenomanian; Shipboard Scientific Party, 1996d) from Cores 159962B-8H and $9 \mathrm{H}$.

\section{Dinoflagellate Cysts}

Core 159-962B-8H is devoid of dinoflagellate cysts. Core 159962B-9H contains Oligosphaeridum buciniferum, Pervosphaeridium cenomaniense, Spiniferites sp. G, and Palaeohystrichophora infusorioides. These species specify a Senonian age. O. buciniferum was reported from the Senonian of Italy (Corradini, 1973). The FAD of $P$. infusorioides is late Albian, and it becomes abundant in the Cenomanian up to the late Campanian. Spiniferites sp. G is located in Section 159-959D-66R-3, at the base of Unit III, which is Coniacian in age. The combined range chart of Spiniferites sp. G and the other species recorded suggest a late Albian-Coniacian age.

\section{Spores and Pollen Grains}

In Cores 159-962B-8H and 9H, some features of the sporomorph assemblages are noteworthy: the absence of Afropollis and of the elater-bearing spores, the coexistence of small and large Classopollis (Classopollis sp. and C. brasiliensis) and the occurrence of Triorites africaensis. Jardiné and Magloire (1965) reported Classopollis sp. S.C.I. 310 and T. africaensis from the Cenomanian of Senegal and of the Ivory Coast (chiefly late and middle Cenomanian of Senegal). Herngreen formally named $C$. brasiliensis this Classopollis sp. S.C.I. 310 and reported it from the late Albian to late Cenomanian of Brazil (1973 as C. jardinei; 1975); this author related in the same papers the occurrence of $T$. africaensis in the upper Cenomanian of Brazil, independently dated. A slight "inconsistency" may be noticed when comparing published records regarding the absence of the elater-bearing spores, for example, which may be explained by the presence of peculiar local paleoecologic conditions. Be that as it may, Subunit IIC probably corresponds more or less to the transition between the palynological sequences VIII and VII of Jardiné and Magloire (1965) or between the pollen Zones II and III of Herngreen (1973), which is equivalent to the boundary between the $C$. brasiliensis Subzone IIB and the Subzone IIIA defined by Herngreen (1975). This boundary traces the early-late Cenomanian boundary.

\section{Hole $962 C$ \\ Dinoflagellates, Spores and Pollen Grains}

The two samples from Unit II and Section 159-962C-1R are barren of palynomorphs.

\section{Hole $962 D$}

Our 51 samples belonging to lithologic Unit III (Sections 159962D-37R-4 through 6R-1 are considered to be late Albian in age (Mascle, Lohmann, Clift, et al., 1996). The distribution of dinocysts and spores and pollen grains found in these samples is tabulated in Figure 3.

\section{Dinoflagellate Cysts}

Thirteen dinoflagellate cyst species are recorded; some are biostratigraphically significant. The FAD of Dinopterygium cladoides is located in the early Albian, the FAD of Palaeohystrichophora infusorioides is known to be in the late Albian (Williams and Bujak, 1985). Pervosphaeridium truncatum was recorded from the late Albian (Masure, 1988) and Cenomanian (Davey, 1969). The absence of Epelidosphaeridia spinosa and Ovoidinium verrucosum ssp. verrucosum, which are elsewhere commonly found in the late Albian, is noteworthy. Sediments from Unit III, Cores 159-962D-37R through $18 \mathrm{R}$, are thus considered Cenomanian in age.

\section{Spores and Pollen Grains}

No significant change appears throughout the section among the sporomorph assemblages. As for Hole 962B, the absence of Afropollis, the coexistence of Classopollis of both sizes, and the occurrence of Triorites africaensis are noticeable. In contrast to the assemblage from Hole 962B, however, two species of the elater-bearing spores are present, namely Elaterosporites protensus and Elaterocolpites castelaini, together with a closely related form, Galeacornea causea; These two latter species were not reported among the assemblages from the other holes. Nevertheless, from a biochronological point of view, the same deduction is made about the age of Unit III of Hole 962D and of the Subunit IIC of Hole 962B, which are close to the early-late Cenomanian boundary.

\section{Palynofacies}

\section{Hole 959D}

Table 1 indicates the volume ( $\mathrm{mL} / 10 \mathrm{~mL}$ of sample) variations of organic matter residue measured after sample demineralization. The highest values $(4.4 \mathrm{~mL} / 10 \mathrm{~mL})$ were measured in black shale samples, Samples 159-959D-66R-1, 33-37 cm (1034.03 mbsf) and 159959D-65R-4, 8-11 cm (1028.68 mbsf), which correspond to peak contents in total organic carbon (5.45 wt\%) (see table 8 and fig. 51, p. 105-106, in Shipboard Scientific Party, 1996a).

Palynofacies of the lowermost samples in lithologic Unit V (Cores 159-959D-76R through 72R) are dominated by small, angular, black, and dark-brown debris (wood and cuticles), almost without amorphous organic matter, reflecting high thermal maturity of organic matter, and also strong terrestrial influences. Palynomorphs are only represented by rare poorly preserved spores and pollen grains. Samples from Cores 159-959D-67R through 44R (from Subunit IVA to Unit III), by contrast, are characterized by mixed structured and amorphous organic matter with higher amounts of amorphous organic matter, indicating significant proportions of marine organic matter. Palynomorphs, mainly represented by dinoflagellate cysts, are light-colored (yellow or translucent), documenting low thermal 


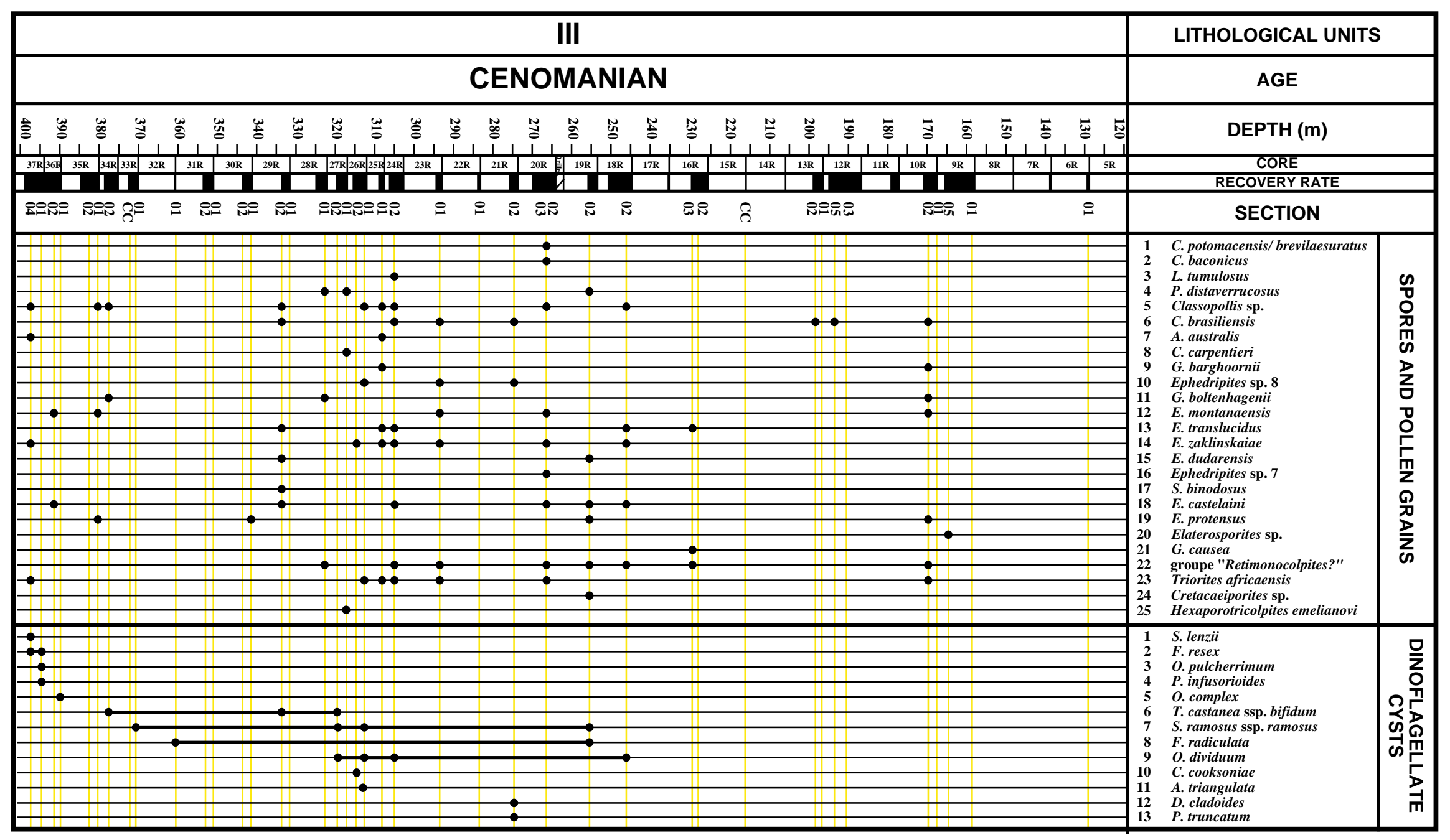

Figure 3. Distribution of dinoflagellate cysts, spores, and pollen grains in Hole 962D 


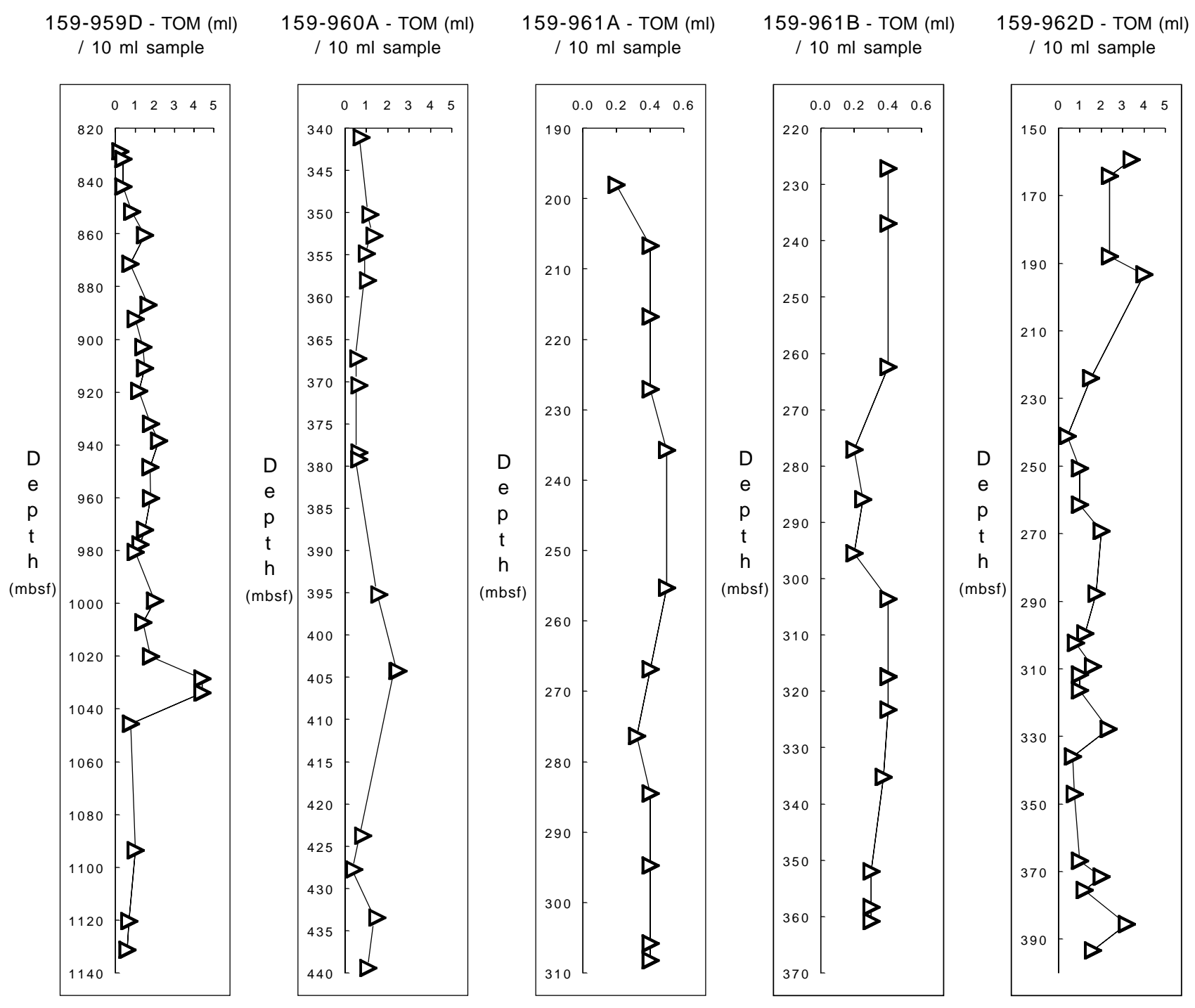

Figure 4. Total organic matter (TOM) content variations of Holes 959D, 960A, 961A, 961B, and 962D.

maturity of organic matter. It should be noted that organic geochemistry analyses (hydrogen index, $\mathrm{T}_{\max }$ ) result in similar conclusions (see "Organic geochemistry" section, in Shipboard Scientific Party, 1996a).

\section{Hole 960A}

Samples of this interval, which includes Subunits VB and VA, show large amplitude variations of organic matter (Table 2; Fig. 4) like the organic carbon contents (see "Organic Geochemistry" section, Shipboard Scientific Party, 1996b).

Palynofacies are mostly characterized by mixed-structured (plant debris), amorphous, always dark-colored organic matter, which suggests first, a high maturity of organic matter, as in Unit $\mathrm{V}$ in Hole 959D, and second, according to organic geochemistry results (hydrogen index, $\mathrm{C} / \mathrm{N}$ ratios), a strong supply of terrestrial material. This is confirmed by palynological assemblages almost entirely composed of spores and pollen grains. Only very rare, poorly preserved, dinoflagellate cysts were observed in some of the uppermost samples, indicating more marine influences. These observations are in accordance with environmental interpretation of lithologic Subunits VB and VA, the first corresponding to lacustrine sediments, the second to shallow marine deposits (see "Lithostratigraphy" section, Shipboard Scientific Party, 1996a).

\section{Hole 960C}

Samples from Core 159-960C-26X (Subunit IVB) are characterized by high amounts of organic matter residue $(4.8 \mathrm{~mL} / 10 \mathrm{~mL}$; Table 2) represented essentially by amorphous organic matter.

\section{Holes $961 A$ and $961 B$}

Samples from these two holes belong to the same Unit III. Sediments yielded very low organic matter contents $(0.2-0.5 \mathrm{~mL} / 10 \mathrm{~mL}$; Table 3; Fig. 4), in contrast to Sites 959 and 960. This is in accordance with organic geochemistry results (Shipboard Scientific Party, 1996c). The generally lower organic carbon contents at Site 961 compared to deposits from Sites 959 and 960 were interpreted as reflecting probably the more pelagic depositional conditions of Site 961. Our palynological observations contradict this interpretation. Palynofacies content, almost exclusively plant debris (wood and cuti- 
cles), spores, and pollen grains, are greatly dominant in palynological assemblages. This suggests strong terrestrial influences in the paleoenvironment.

\section{Hole $962 B$}

Samples from Core 159-962B-9H, in contrast to Core 159-962B$8 \mathrm{H}$, yielded high amounts of organic matter (Table 4), in accordance with the organic geochemistry results. Organic carbon values are remarkably high in this core, the $\mathrm{C} / \mathrm{N}$ ratio and hydrogen index suggest a mixed marine-terrestrial origin for the organic matter. $\mathrm{T}_{\max }$ values in this core are indicative of a thermal immature level (see "Organic Geochemistry" section, Shipboard Scientific Party, 1996d). This explains the very good preservation of palynomorphs represented by dominant spores and pollen grains, but also by some dinoflagellate cysts.

\section{Hole $962 D$}

As shown in Table 4, samples display highly variable organic matter contents in accordance with organic geochemistry results (Shipboard Scientific Party, 1996d). Palynofacies are characterized by mixed-structured and amorphous organic matter, indicating a mixed marine-terrestrial origin of the organic matter. Palynomorphs represented by spores and pollen grains, dinoflagellate cysts, and frequent foraminifers are very well preserved here.

\section{CONCLUSIONS}

\section{Biostratigraphy}

Concerning the biostratigraphical results, most samples were fossiliferous and yielded more or less well-preserved palynomorphs (spores, pollen grains, acritarchs, dinoflagellate cysts, and foraminifers) and more or less diversified assemblages. On the whole, 44 spore and pollen grain species or indeterminable forms representing 27 genera were identified, as well as 82 dinoflagellate cyst species representing 48 genera.

From the palynostratigraphic discussion above, the following age conclusions can be made (see Fig. 5).

\section{Hole 959D}

Late Barremian to middle Albian for Unit V, from Core 159959D-72R (Sections 159-959D-76R-2 through 72R-2; 1131.56$1093.00 \mathrm{mbsf}$ ) using sporomorphs; no age using dinoflagellate cysts.

No age for Subunit IVB; no samples.

?Coniacian for Subunit IVA and Unit III in part, from Section 159-959D-67R-2 to 65R-4 (1045.71-1028.68 mbsf); ?Coniacian using dinoflagellate cysts; middle Cenomanian to early Coniacian using spores and pollen grains.

Santonian for Unit III in part, from Section 159-959D-65R-2 to 62R-1 (1025.87-996.16 mbsf) using dinoflagellate cysts; no data using sporomorphs.

Campanian for Unit III in part, from Section 159-959D-60R-4 to 58R-3 (980.76-960.03 mbsf) using dinoflagellate cysts; no data using sporomorphs.

Maastrichtian for Unit III in part, from Section 159-959D-57R-4 to 53R-3 (952.74-910.97 mbsf) using dinoflagellate cysts; no data using sporomorphs.

Paleocene, Danian for Unit III in part, from Section 159-959D52R-3 to 45R-1 (903.09-831.94 mbsf) using dinoflagellate cysts; no data using sporomorphs.

Paleocene, late Thanetian for Unit III, Section 159-959D-44R-6 (828.70 mbsf) using dinoflagellate cysts.
Spores and pollen grains give a late Barremian to middle Albian age for the previously undated oldest sediments of Unit V. Dinoflagellate cysts determine the stage boundaries of the undifferentiated Late Cretaceous from Section 159-959D-64R through 44R of Unit III (Shipboard Scientific Party, 1996a, fig. 27, p. 88) and characterize the Danian. A hiatus is probably present in the late Campanian; no hiatus is suspected in the early Paleocene. The Danian is present.

\section{Hole $960 A$}

Late Barremian to middle Albian for Unit V, from Section 159960A-61R-1 to 38R-2 (446.28-340.40 mbsf) using spores and pollen grains; no age determination with dinoflagellate cysts. No palynostratigraphic difference was observed between Subunits VA and VB, which were previously considered of unknown age.

\section{Hole 960C}

No more precision on age for Subunit IVB of Sections 159-960C26X and 25X (345.14-333.68 mbsf) using dinoflagellate cysts (late Cenomanian to late Maastrichtian) and sporomorphs. The interval is Turonian to Coniacian in age, according to Shipboard Scientific Party (1996b).

\section{Holes $961 A$ and $961 B$}

Middle Albian using spores and pollen grains for Unit III, Hole 961A, from Section 159-961A-35R-1 to 22R-2 (308.37-198.07 mbsf) and Hole 961B, from Section 159-961B-17R-1 to $2 \mathrm{R}-1$ (361.25 to $226.22 \mathrm{mbsf}$ ); no data using dinoflagellate cysts.

\section{Hole $962 B$}

Cenomanian (early/late boundary) for Subunit IIC, from Section 159-962B-9H to $8 \mathrm{H}$ (79.15-66.30 mbsf); Cenomanian (early/late boundary) using sporomorphs; Albian to Coniacian using dinoflagellate cysts. This result determines the age assignment of Subunit IIC, which was previously dated as late Albian to Cenomanian.

\section{Hole $962 C$}

No age for Subunit II, from Sections 159-962C-1R-CC and 1R-1 (73.29- 73.05); no sporomorph or dinocyst data.

\section{Hole $962 D$}

Cenomanian (early/late boundary) for Unit III, from Section 159962D-37R-4 to 6R-1 (393.49-123.76 mbsf); Cenomanian (early/late boundary) using sporomorphs; Cenomanian using dinoflagellate cysts. Unit III of Hole 962D was previously considered late Albian in age.

\section{Palaeofloral Provinces}

Along the Cretaceous, three palynofloral provinces succeeded, one after the other, in spreading their successive realms over the equatorial belt (Herngreen et al., 1996), namely, the "Pre-Albian Early Cretaceous Dicheiropollis etruscus/Afropollis Province," then the "Albian to Cenomanian Elaterates Province," and finally the "Senonian Palmae Province." The terrestrial microfloras indicate in which of these provinces the deposition of the Leg 159 units or subunits took place.

Unit V of Holes 959D and 960A may have been deposited either while the realm of the "Pre-Albian Early Cretaceous Dicheiropollis 

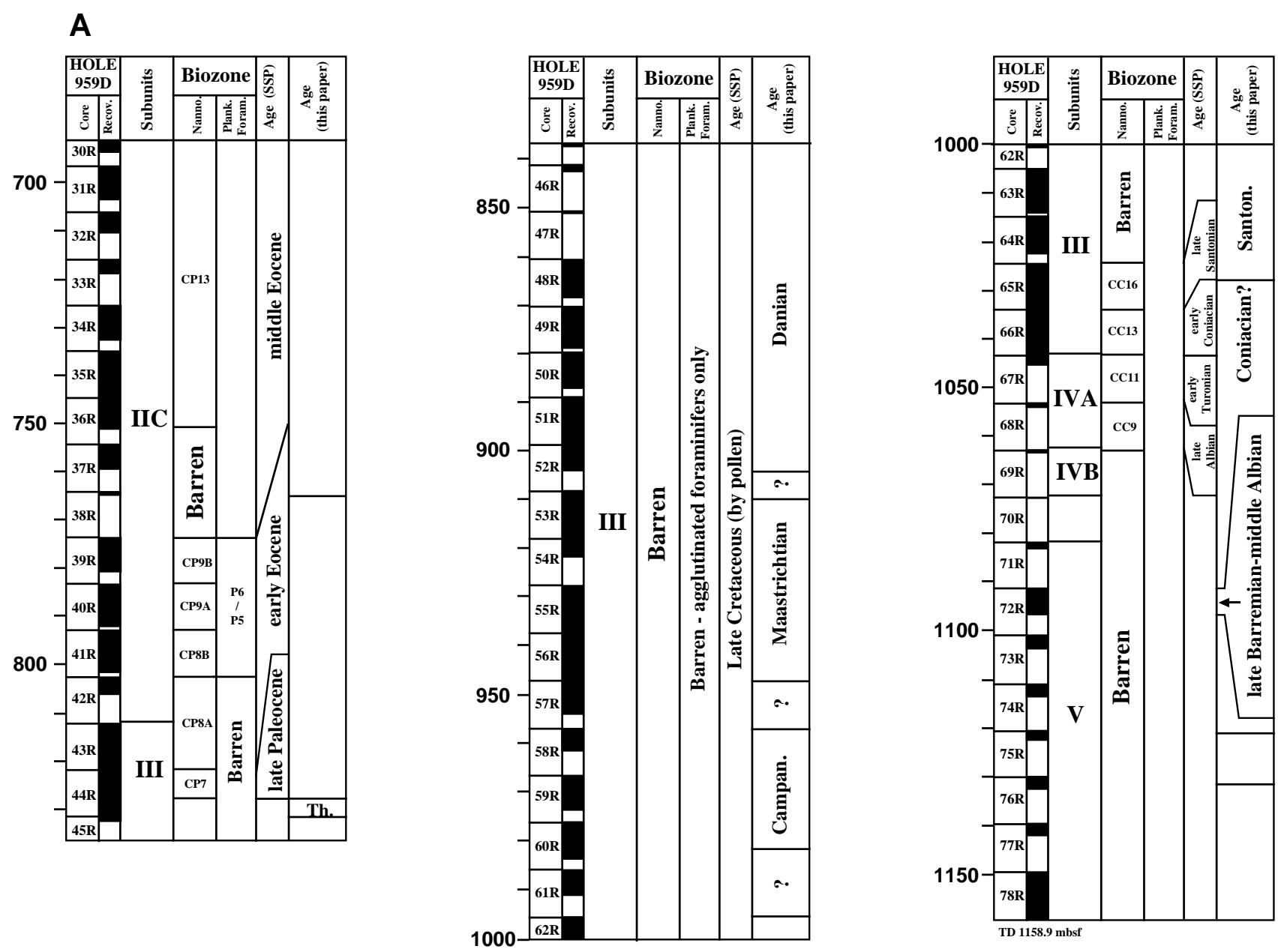

Figure 5. A. Biostratigraphic results for Hole 959D according to Shipboard Scientific Party (1996a) and this paper. (Continued next page.)

etruscus/Afropollis Province" was still settled, or during the transition between this province and the following one, the "Albian-Cenomanian Elaterates Province," or even after the latter province had already settled.

The overlying Subunit IVA of Hole 959D deposited likewise in the realm of two consecutive provinces, the "Albian-Cenomanian Elaterates Province" and the "Senonian Palmae Province".

Unit III of Holes 961A, 961B, 962D, and Subunit IIC of Hole 962B were deposited under the realm of the "Albian-Cenomanian Elaterates Province".

\section{Palynofacies and Paleoenvironments}

Three main types of palynofacies can be distinguished that indicate the environmental conditions of deposits.

The first type is principally characterized by structured organic debris, spores, and pollen grains, with or without very rare, poorly preserved dinoflagellate cysts. This palynofacies type is also characterized by high thermal maturity of organic matter. The oldest deposits, Unit V, late Barremian to middle Albian, from Holes 959D and 960A, and Unit III, middle Albian, from Holes 961A and 961B, belong to this type. During the late Barremian to middle Albian times, deposits with strong terrestrial conditions of Sites 959, 960, and 961 were heated either because of the proximity of the transform margin activity or of the young oceanic lithosphere.
The second type is an intermediate palynofacies with mixedstructured and amorphous organic matter. Palynomorphs are principally represented by spores and pollen grains, as well as by more or less numerous marine microfossils. This palynofacies type is characterized by immature organic matter. Samples of Subunit IIC from Hole 962B (Cenomanian) and samples of Unit III from Hole 962D (also Cenomanian) belong to this type. The second palynofacies type reveals mixed marine and terrestrial depositional conditions during the Cenomanian at Site 962.

The third type is characterized by abundant, amorphous, thermally immature organic matter, numerous dinoflagellate cysts, and foraminifers. It indicates clear marine depositional conditions, which prevailed from the ?Coniacian through the late Paleocene at Site 959 (upper part of Unit IVA, and Unit III) and during the Cenomanian at Site 960 (Subunit IVB).

\section{TAXONOMY}

All dinoflagellate cyst taxa and spores and pollen grains found at Sites 959, 960, 961, and 962 are listed (dinoflagellate cysts in alphabetical order, spores and pollen grains by morphographical group), with references to plates and figures as well as number and position on the distribution charts. In the taxa lists, the number in parentheses refers to the position on the distribution chart of Holes 959D (Fig. 2) and 962D (Fig. 3), respectively. A "(-)" notes the taxon's absence. The taxa list for dinoflagellate cysts is followed by morpho- 

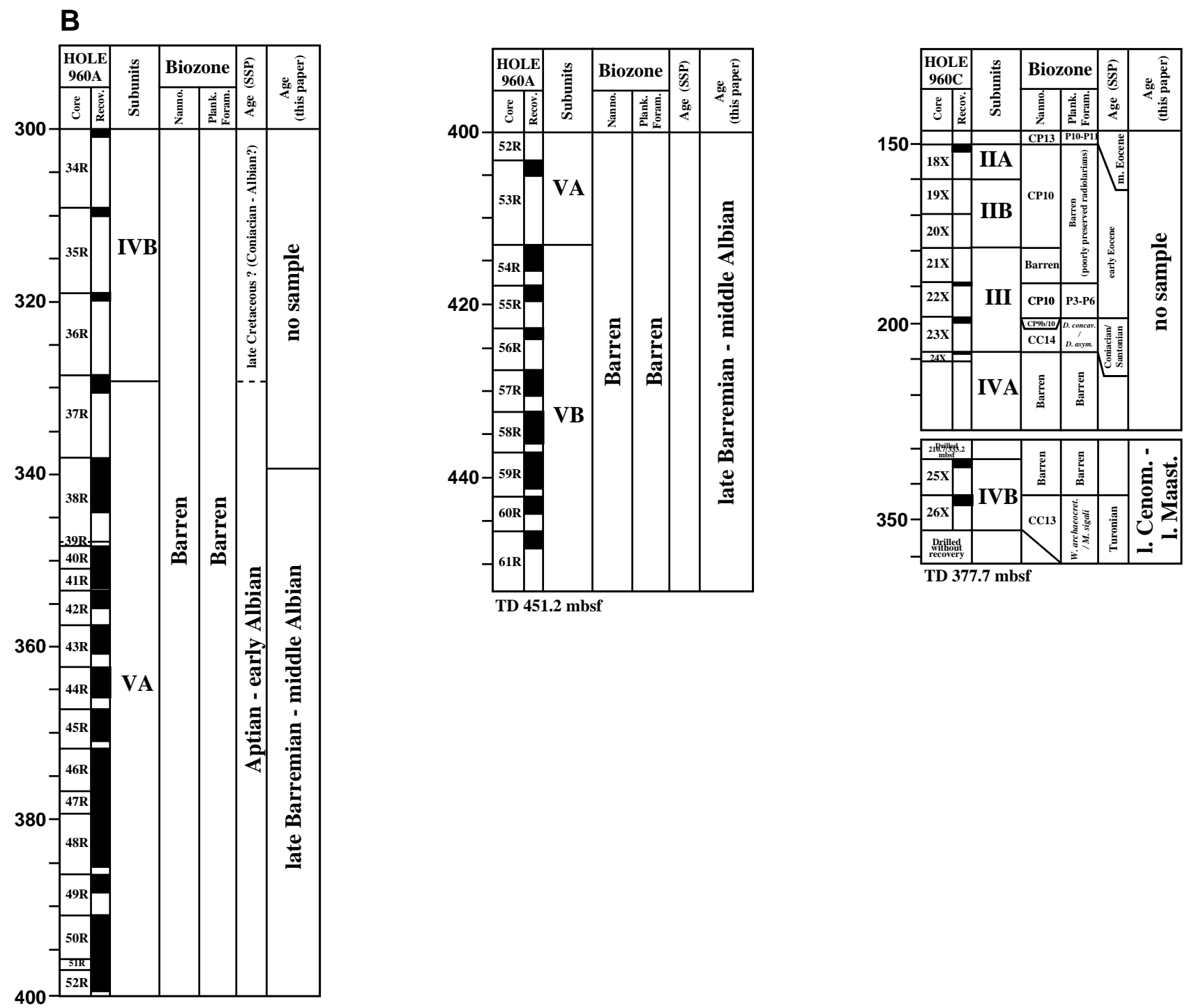

Figure 5 (continued). B. Biostratigraphic results for Holes 960A and 960C according to Shipboard Scientific Party (1996b) and this paper. (Continued next page.)

logical descriptions of new species. This systematic section is arranged alphabetically according to genus.

Achilleodinium bianii Hultberg, 1985; Plate 1, Figures 1, 2 (64) (-). Achomosphaera triangulata (Gerlach, 1961) Davey and Williams, 1969 (10) (11).

Achomosphaera verdieri Below, 1982 (13) (-).

Adnatosphaeridium multispinosum Williams and Downie, 1966; Plate 1, Figure 3 (72) (-).

Alterbidinium varium Kirsch, 1991; Plate 1, Figure 4 (36) (-).

Andalusiella gabonensis (Stover and Evitt, 1978) Wrenn and Hart, 1988; (38) $(-)$.

Andalusiella ivoirensis Masure et al., 1996; Plate, 1, Fig; 5 (34) (-). Andalusiella mauthei subsp. mauthei Riegel, 1974, emend. Riegel and Sarjeant, 1982, emend. Masure et al., 1996; Plate, 1, Figure 6 (26) (-).

Andalusiella mauthei subsp. punctata (Jain and Millepied, 1973) Masure et al., 1996, emend. Masure et al., 1996; (23) (-).

Andalusiella rhomboides (Boltenhagen, 1977) Lentin and Williams, 1980, emend. Masure et al., 1996; Plate 1, Figure 7 (27) (-).

Areoligera coronata (O. Wetzel, 1933b) Lejeune-Carpentier, 1938; (54) (-). Areoligera senonensis Lejeune-Carpentier, 1938; (39) (-).
Areoligera volata Drugg, 1967; Plate 1, Figure 8 (44) (-).

Cerodinium diebelii (Alberti, 1959) Lentin and Williams, 1987; Plate 1, Figure 9 (40) (-).

Cerodinium granulostriatum (Jain and Millepied, 1973) Lentin and Williams, 1987; Plate 1, Figure 10 (30) (-).

Cerodinium leptodermum (Vozzhennikova, 1963) Lentin and Williams, 1987; (41) (-).

Cordosphaeridium inodes (Klumpp, 1953) Eisenack, 1963, emend. Morgenroth, 1968, emend. Sarjeant, 1981; (73) (-).

Cordosphaeridium cf. inodes (Klumpp, 1953) Eisenack, 1963, emend. Morgenroth, 1968, emend. Sarjeant, 1981; Plate 1, Figure 11 (46) (-).

Cordosphaeridium varians May, 1980; Plate 1, Figure 12 (50) (-).

Coronifera oceanica Cookson and Eisenack, 1958; (11) (-).

Cribroperidinium cooksoniae Norvick in Norvick and Burger, 1976; (-) (10).

Cyclonephelium deconinckii Boltenhagen, 1977; Plate 1, Figure 13 (6) (-).

Damassadinium californicum (Drugg, 1967) Fensome et al., 1993; Plate 1, Figure 14 (55) (-).

Dapsilidinium laminaspinosum (Davey and Williams, 1966b) Lentin and Williams, 1981; (33) (-).

Dinogymnium cretaceum (Deflandre, 1935) Evitt et al., 1967; (3) (-). 
Figure 5 (continued). C. Biostratigraphic results for Holes 961A and 961B according to Shipboard Scientific Party (1996c) and this paper. (Continued next page.)

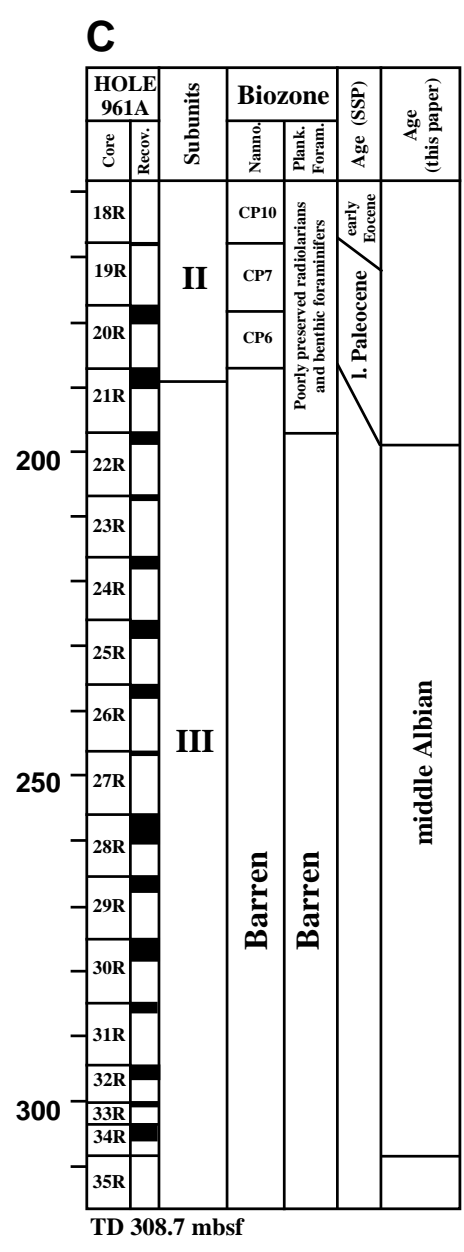

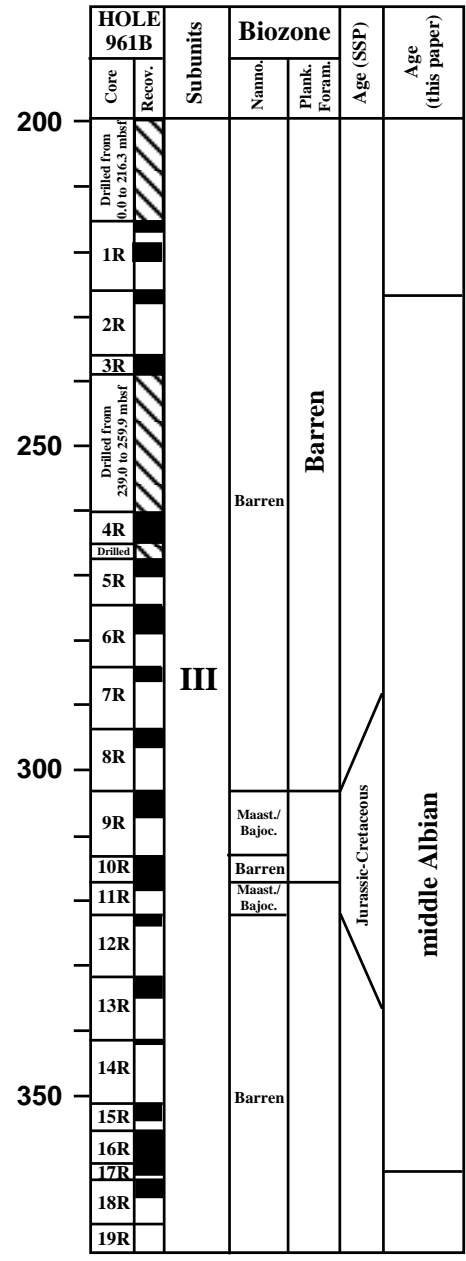

TD 374.6 mbsf
Dinogymnium denticulatum (Alberti, 1961) Evitt et al., 1967; Plate 1, Figure $15(15)(-)$.

Dinogymnium vozzhennikovae Lentin and Williams, 1973 nom subst. pro Gymnodinium albertii Vozzhennikova, 1967 non Dinogymnium albertii Clarke and Verdier, 1967, emend. Lentin and Vozzhennikova, 1990; (51) $(-)$.

Dinopterygium cladoides Deflandre, 1935; (-) (12).

Epelidosphaeridia spinosa (Cookson and Hughes, 1964) Davey, 1969; (-) (-). Exochosphaeridium bifidum (Clarke and Verdier, 1967) Clarke et al., 1968; Plate 1, Figure 16. (57) (-).

Fibradinium annetorpense Morgenroth, 1968; Plate 2, Figures 1, 2 (57) (-).

Fibrocysta axialis (Eisenack, 1965) Stover and Evitt, 1978; Plate 2, Figure 3 (56) (-).

Fibrocysta bipolaris (Cookson and Eisenack, 1965) Stover and Evitt, 1978; (65) (-).

Fibrocysta radiata (Morgenroth, 1966) Stover and Evitt, 1978; (66) (-).

Florentinia radiculata (Davey and Williams, 1966b) Davey and Verdier, 1973; (16) (8).

Florentinia resex Davey and Verdier, 1976; Plate 2, Figure 4 (2) (2).

Glaphyrocysta wilsonii Kirsch, 1991; Plate 2, Figure 5 (48) (-).

Hystrichodinium pulchrum subsp. densispinum (Deflandre,1936) Lentin and Williams, 1973; (9) (-).

Hystrichodinium cf ramoides Alberti, 1961; Plate 2, Figure 6 (21) (-).

Impagidinium celineae Jan du Chêne, 1988; Plate 2, Figure 7 (59) (-).

Isabelidinium acuminatum (Cookson and Eisenack, 1958) Stover and Evitt, 1978; (18) (-).

Kallosphaeridium yorubaense Jan du Chêne and Adediran, 1985; Plate 2, Figure 8 (67) (-)
Kenleyia lophophora Cookson and Eisenack, 1965; Plate 2, Figure 10 (53) (-). Kenleyia pachycerata Cookson and Eisenack, 1965; Plate 2, Figure 9 (68) (-). Kleithriasphaeridium loffrense Davey and Verdier, 1976; (37) (-).

Liesbergia abdounensis Soncini, 1992; Plate 2, Figure 11 (60) (-).

Microdinium densigranulatum (Below, 1987) Lentin and Williams, 1989; (63) (-).

Odontochitina operculata (O. Wetzel, 1933a) Deflandre and Cookson, 1955; (28) (-).

Odontochitina porifera Cookson, 1956; Plate 2, Figure 12 (31) (-).

Oligosphaeridium buciniferum Corradini, 1973

Oligosphaeridium complex (White, 1842) Davey and Williams, 1966b; (-) (5).

Oligosphaeridium dividuum Williams, 1978; (4) (9).

Oligosphaeridium porosum Lentin and Williams, 1981, nom subst. pro Oligosphaeridium perforatum Jain, 1977, non Oligosphaeridium perforatum (Gocht, 1959) Davey and Williams, 1969; (22) (-).

Oligosphaeridium pulcherrimum (Deflandre and Cookson, 1955) Davey and Williams, 1966b; Plate 2, Figure 13 (20) (3).

Ovoidinium verrucosum ssp. verrucosum (Cookson and Hughes, 1964) Davey, 1970.

Palaeocystodinium australinum (Cookson, 1965) Lentin and Williams, 1976; Plate 2, Figure 13 (42) (-).

Palaeohystrichophora infusorioides Deflandre, 1935; (7) (4).

Perisseiasphaeridium pannosum Davey and Williams, 1966b; Plate 2, Figs. 15, $16(71)(-)$.

Pervosphaeridium cenomaniense (Norvick in Norvick and Burger, 1976) Below, 1982; (-) (-) 

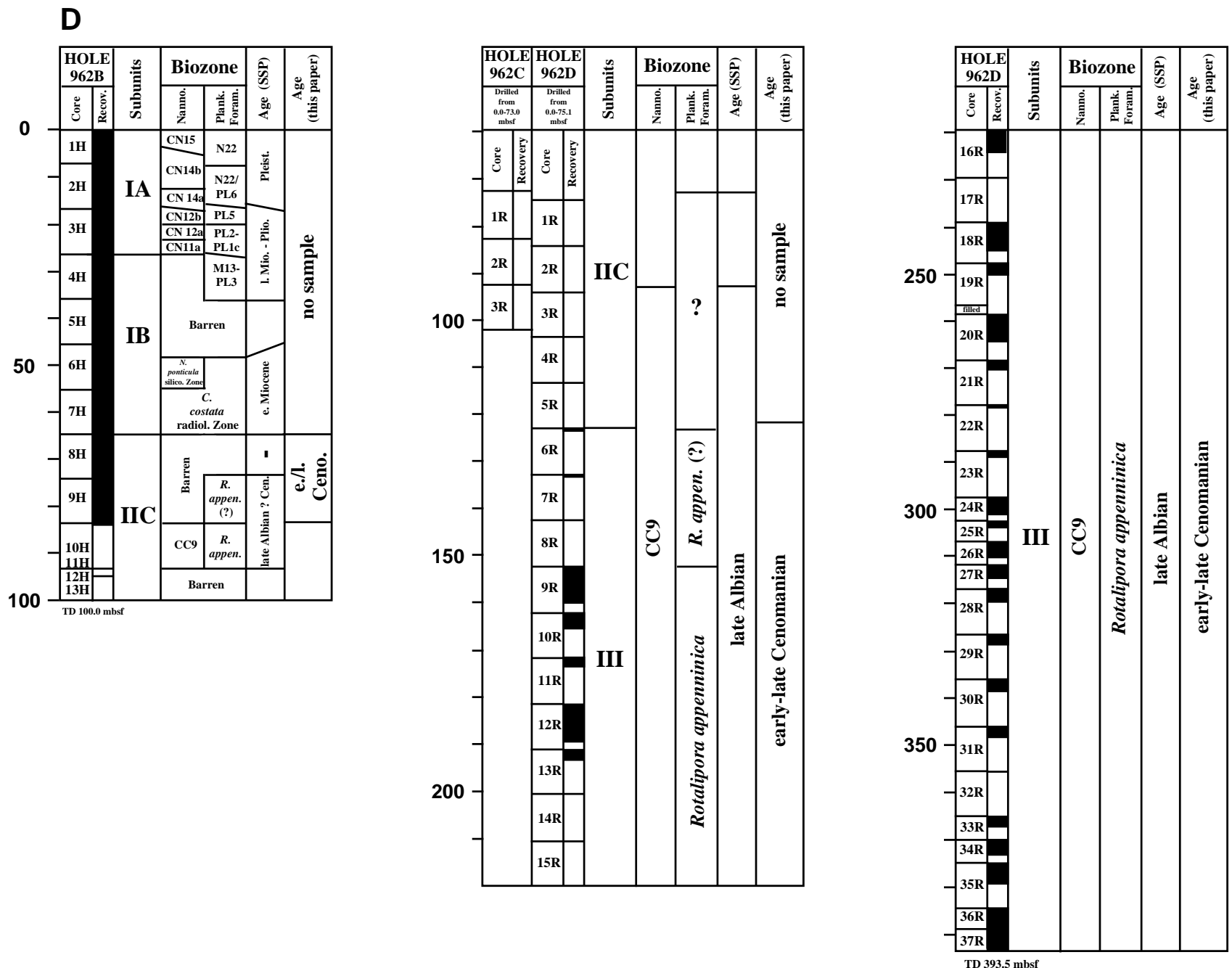

Figure 5 (continued). D. Biostratigraphic results for Holes 962B, 962C, and 962D according to Shipboard Scientific Party (1996d) and this paper.

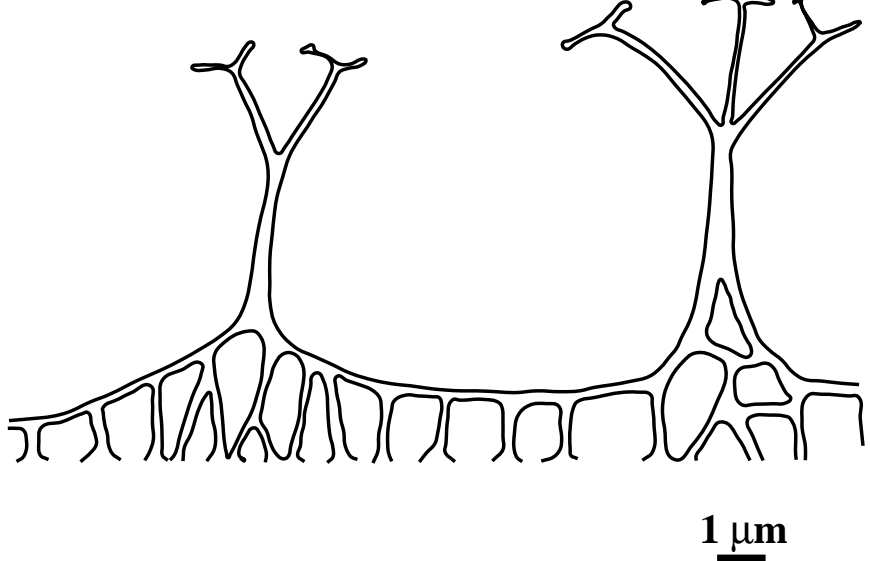

Figure 6. Bridge-like structures of the parasutural septa of Spiniferites bejuii n. sp.
Pervosphaeridium truncatum (Davey, 1969) Below, 1982, emend. Masure, 1988b; (-) (13).

Phelodinium magnificum (Stanley, 1965) Stover and Evitt, 1978; Plate 3, Figure $1(24)(-)$.

Pterodinium cingulatum subsp. cingulatum (O. Wetzel, 1933b) Below, 1981; (43) (-).

Senegalinium laevigatum (Malloy, 1972) Bujak and Davies, 1983; Plate 3,

Figure 2 (32) (-).

Spiniferites bejuii n. sp.; Plate 3, Figures 3, 4 (5) (-).

Spiniferites cornutus susp. cornutus (Gerlach, 1961) Sarjeant, 1970; Plate 3, Figure 5 (69) (-).

Spiniferites fluens (Hansen, 1977) Stover and Williams, 1987; Plate 3, Figure 6. (45) (-).

Spiniferites hyalospinosus (Hansen, 1977) Stover and Williams, 1987; Plate 3, Figure 7 (70) (-).

Spiniferites lenzii Below, 1982; (-) (1).

Spiniferites multibrevis (Davey and Williams, 1966a) Below, 1982; (29) (-).

Spiniferites pseudofurcatus (Klumpp, 1953) Sarjeant, 1970; (47) (-).

Spiniferites ramosus subsp. ramosus (Ehrenberg, 1838) Loeblich and Loeblich, 1966; (17) (7).

Spiniferites tripus Singh, Ch. 1983; (52) (-).

Spiniferites sp.G; Plate 3, Figure 8 (12) (-).

Subtilisphaera cheit Below, 1981; (8) (-).

Tanyosphaeridium xanthiopyxides (O. Wetzel, 1933b, emend. Morgenroth, 1968) Stover and Evitt, 1978; Plate 3, Figure 9 (61) (-). 


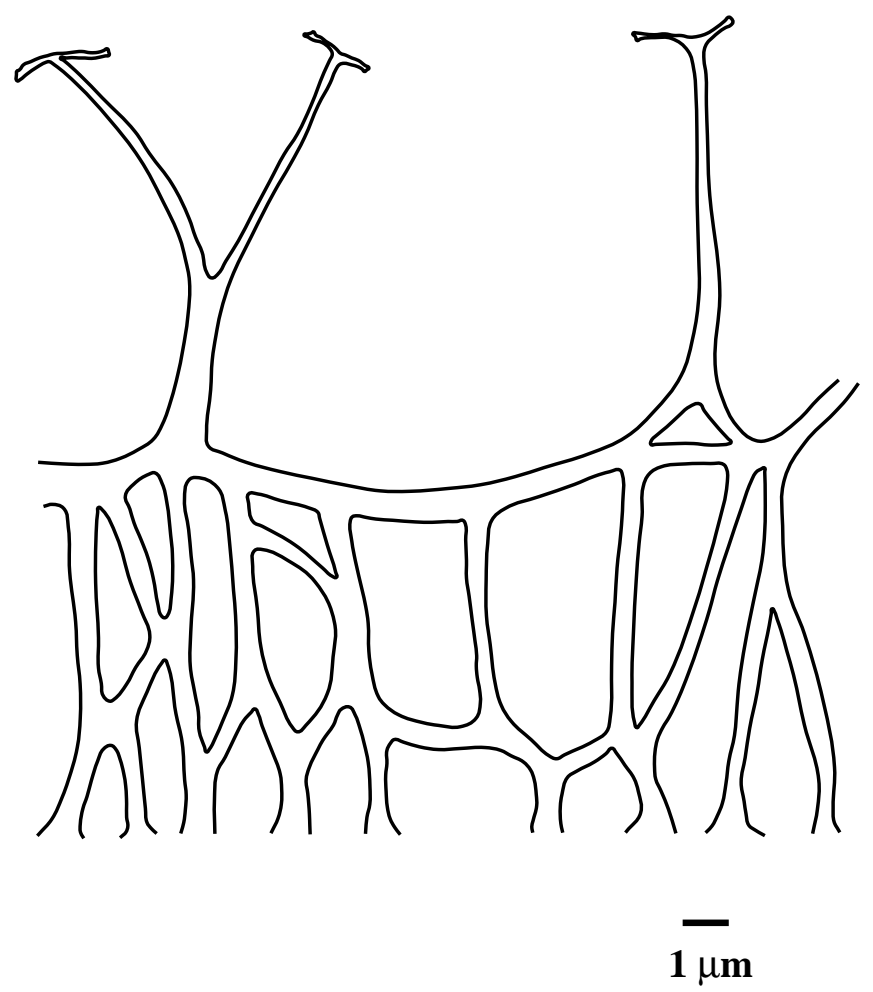

Figure 7. Ramified bridge-like structures of the parasutural septa of Spiniferites sp. G.

Tectatodinium rugulatum (Hansen, 1977) McMinn, 1988; Plate 3, Figure 10 (62) (-).

Trichodinium castanea subsp. bifidum (Jain and Millepied, 1975) Schrank, 1987; Plate 3, Figure 11 (25) (6).

Trithyrodinium druggii Stone, 1973; Plate 3, Figure 12 (49) (-).

Unipontidinium grande (Davey, 1975) Wrenn, 1988; Plate 3, Figure 13 (19) $(-)$.

Xenascus ghanaensis n. sp.; Plate 3, Figures 14, 15 (35) (-).

Xenascus gochtii (Corradini, 1973) Stover and Evitt, 1978; Plate 3, Figure 16 (1) (-).

Xiphophoridium alatum (Cookson and Eisenack, 1962) Sarjeant,1966; (14) $(-)$.

\section{DESCRIPTIONS}

Class DINOPHYCEAE Fritsch, 1929

Order PERIDINIALES Haeckel, 1894 Genus SPINIFERITES Mantell, 1850; emend. Sarjeant, 1970

Type species. Spiniferites ramosus (Ehrenberg, 1838; Pl. 1, Figs. 1, 2, 5) Mantell, 1854, p. 239.

\section{Spiniferites bejuii $\mathrm{n} . \mathrm{sp}$}

(Pl. 3, Figs. 3, 4; Fig. 6)

Derivation of name: In honor of Dr. Beju, palynologist.

Diagnosis: Dinoflagellate cysts skolochorate; body subspherical, bearing gonal and intergonal processes; processes connected at their bases by low parasutural bridge-like septal structures; gonal processes proximally ramified, distally trifurcate; intergonal processes proximally ramified, distally bifurcate; gonyaulacoid paratabulation indicated mainly by parasutural septa and gonal processes, archeopyle precingular, type $\mathrm{P}$, free operculum.

Holotype: Slide 1: F 34, Sample 159-959D-65R-2, 27-30 cm.

Type locality: Hole 959D, offshore Côte d'Ivoire and Ghana, Côte d'Ivoire-Ghana Transform Margin.
Type biohorizon: Santonian, $1025.87 \mathrm{mbsf}$.

Housed: In the Centre Scientifique Georges Deflandre of the National Museum of Natural History in Paris, France.

Dimensions: Holotype: length of central body $48 \mu \mathrm{m}$, total length of processes $10 \mu \mathrm{m}$, height of parasutural septa, up to $4 \mu \mathrm{m}$. 10 specimens measured. Length of central body, $48(51) 65 \mu \mathrm{m}$, length of processes $7(10) 15 \mu \mathrm{m}$, length of parasutural septa $1(2.2) 4 \mu \mathrm{m}$.

Description: Shape: skolochorate dinoflagellate cyst, with subspherical central body. Wall relationship: composed of a periphragm and an endophragm appressed. Wall features: periphragm with scabrate surface; solid gonal and intergonal processes, without membrane, proximally ramified, connected by parasutural septa formed by solid bridge-like structures; gonal process tips with trifide primary furcation and bifide secondary furcation; intergonal process tips with bifide primary and secondary bifurcations; endophragm smooth. Paratabulation: gonyaulacoid indicated by parasutural septa combined with processes: ?pr, 3-4', 5-6", 6c, 5-6"', 1p, 1'"', Xs. Paracingulum: indicated by parasutural septa and processes. Parasulcus indicated by parasutural features. Archeopyle precingular, type P (3") with free operculum.

Comparison: S. bejuii differs from other species of the genus in having parasutural septa formed by solid bridge-like elements and gonal and intergonal processes resting on ramified bases.

Occurrence: Hole 959D (see Fig. 2, number 5), from Sample 159-959D67R-2, 57-61 cm (1045.37 mbsf), to Sample 159-959D-65R-1, 92-95 cm (1015.62 mbsf), Coniacian? to Santonian.

\section{Spiniferites $\mathrm{sp} . \mathrm{G}$ (Pl. 3, Fig. 8; Fig. 7)}

Specimen: Slide 1: VW 47-48, Sample 159-959D-66R-3, 40-43 cm. Biohorizon: Coniacian?, $1037.10 \mathrm{mbsf}$.

Dimensions: Total length, $76 \mu \mathrm{m}$; length of parasutural septa up to $8 \mu \mathrm{m}$, length process $8 \mu \mathrm{m}$, length of parasutural feature $16 \mu \mathrm{m}$.

Description: Shape: skolochorate dinoflagellate cyst, with subspherical central body. Wall relationship: composed of a periphragm and of an endophragm appressed. Wall features: smooth periphragm; solid gonal and intergonal processes, round in section, connected by parasutural septa formed by solid ramified bridge-like structures; gonal process tips with trifide primary furcation and bifide secondary furcation; intergonal process tips with bifide primary and secondary bifurcations; endophragm smooth. Paratabulation: gonyaulacoid indicated by parasutural septa combined with processes: ?pr, 3$4^{\prime}, 5-6^{\prime \prime}, 6 \mathrm{c}, 5-6^{\prime \prime \prime}, 1 \mathrm{p}, 1^{\prime \prime \prime \prime}$, Xs. Paracingulum: indicated by parasutural septa and processes. Parasulcus: indicated by parasutural septa. Archeopyle: precingular, type $\mathrm{P}\left(3^{\prime \prime}\right)$ with free operculum.

Remark: Only one specimen observed. Spiniferites sp.G and Spiniferites bejuii n. sp. are referable to the same complex. Parasutural septa of Spiniferites $\mathrm{sp} . \mathrm{G}$ are more developed than those of Spiniferites bejuii $\mathrm{n}$. sp.

Genus XENASCUS Cookson and Eisenack, 1969; emend. Yun, 1981; emend. Stover and Helby, 1987.

Type species. Xenascus australensis Cookson and Eisenack, 1969, p. 7, figs. 1I-K.

$$
\text { Xenascus ghanaensis } \mathrm{n} . \mathrm{sp} \text {. }
$$$$
\text { (P1. 3, Figs. 14, 15; Table 5) }
$$

Derivation of name: In connection with the geographical location of Leg 159, offshore Ghana.

Diagnosis: Dinoflagellate cysts proximochorate, circumcavate with ceratoid outline, with three prominent truncated horns; smooth endophragm, granulate periphragm with few short spines and processes arranged more or less parasuturally; archeopyle apical, type (tA), free polyplacoid operculum.

Holotype: Slide 2: U24, Sample 159-959D-57R-2, 12-15 cm.

Paratype 1: Slide 1: P37, Sample 159-959D-57R-2, 12-15 cm.

Paratype 2: Slide 2: W22, Sample 159-959D-57R-2, 12-15 cm.

Type locality: Hole 959D, offshore Ghana and Côte d'Ivoire, Côte d'Ivoire-Ghana Transform Margin.

Type biohorizon: Maastrichtian, $948.72 \mathrm{mbsf}$.

Housed: In the Centre Scientifique Georges Deflandre of the National Museum of Natural History in Paris, France.

Dimensions: Holotype: Total length $136 \mu \mathrm{m}$; epicyst, central body length $16 \mu \mathrm{m}$, apical horn length $36 \mu \mathrm{m}$, total length $52 \mu \mathrm{m}$; hypocyst length $84 \mu \mathrm{m}$. 
Table 5. Dimensions of specimens of Xenascus ghanaensis n. sp.

\begin{tabular}{|c|c|c|c|c|c|c|c|}
\hline Specimen & $\begin{array}{l}\text { Antapical horn } \\
\qquad(\mu \mathrm{m})\end{array}$ & $\begin{array}{c}\text { Central body length } \\
(\mu \mathrm{m})\end{array}$ & $\begin{array}{l}\text { Total length } \\
\quad(\mu \mathrm{m})\end{array}$ & $\begin{array}{l}\text { Central body diameter } \\
\qquad(\mu \mathrm{m})\end{array}$ & $\begin{array}{l}\text { Right lateral coel } \\
\qquad(\mu \mathrm{m})\end{array}$ & $\begin{array}{l}\text { Left lateral coel } \\
\qquad(\mu \mathrm{m})\end{array}$ & $\begin{array}{l}\text { Total diameter } \\
\qquad(\mu \mathrm{m})\end{array}$ \\
\hline Holotype: & 41 & 43 & 84 & 57 & 16 & 11 & 84 \\
\hline Paratype 1: & 40 & 68 & 108 & 62 & 21 & 18 & 101 \\
\hline Paratype 2: & 32 & 56 & 88 & $56 \mathrm{~m}$ & 20 & 16 & 92 \\
\hline Specimen slide 2, L 27: & 38 & 49 & 87 & 56 & 16 & 12 & 84 \\
\hline Specimen slide 2, W 22 : & 37 & 65 & 102 & 64 & 16 & 16 & 96 \\
\hline Measurement range: & $32(37.6) 41$ & $43(56) 68$ & $84(94) 108$ & $56(59) 64$ & $16(17.8) 21$ & $11(14.6) 18$ & 84 (91.4) 101 \\
\hline
\end{tabular}

Note: Range measurements = minimum, (average), maximum

Description: Shape: pericyst outline ceratioid, with prominent truncated horns, endocyst subspherical to ellipsoidal. Wall relationship: cyst circumcavate. Periphragm forms: one apical, one antapical, and one cingular horn, and a large pericoel around margin of central body in dorsoventral view. Wall features: granulate periphragm, rare parasutural spines or processes on dorsal precingular and postcingular paraplates, on paracingular margins and on the apical horn; distal ends of truncated horns perforated; scabrate endophragm. Paratabulation: epicyst, principal archeopyle sutures indicate four apical paraplates and six precingular paraplates; hypocyst, not determined. Paracingulum: indicated by cingular horn and alignment of rare processes or spines. Parasulcus: indicated anteriorly by the offset parasulcal notch. Archeopyle: apical type (tA), free polyplacoid operculum.

Comparison: Xenascus ghanaensis n. sp. differs from other species of the genus in having a large pericoel around the margin of the central body in dorsoventral view and prominent truncated horns.

Occurrence: Hole 959D (see Fig. 2, number 35) from Sample 159-959D57R-4, 114-117 cm (952.74 mbsf), to 56R-4, 60-62 cm (942.50 mbsf); Maastrichtian.

\section{TAXA LIST FOR SPORES, POLLEN GRAINS, AND ACRITARCHS}

Following the scheme proposed by Potonié and Kremp (1954), then essentially modified by Dettmann (1963) and Potonié (1970).

Anteturma Proximegerminantes Potonié, 1970.

Turma Triletes Azonales (Reinsch, 1881) Potonié and Kremp, 1954.

Subturma Azonotriletes Luber, 1935.

Infraturma Laevigati (Bennie and Kidston, 1886) Potonié, 1956. Deltoidospora minor (Couper, 1953) Pocock, 1970.

Dictyophyllidites harrisii Couper, 1958.

Todisporites $\mathrm{sp}$.

Infraturma Apiculati (Bennie and Kidston, 1886) Potonié, 1956. Subinfraturma Verrucati Dybová and Jachowicz, 1957.

Leptolepidites tumulosus (Döring, 1964) Srivastava, 1975 (-) (3).

Patellasporites distaverrucosus (Brenner, 1963) Kemp, 1970 (-) (4).

Infraturma Murornati Potonié and Kremp, 1954.

Cicatricosisporites baconicus Deák, 1963 (-) (2).

Cicatricosisporites of the "potomacensis-brevilaesuratus group" (-) (1).

Klukisporites variegatus Couper, 1958.

Turma Vestititriletes Potonié, 1970.

Suprasubturma Perinotrilites (Erdtman, 1947) Dettmann, 1963.

Crybelosporites pannuceus (Brenner, 1963) Srivastava, 1975; Plate 4, Figure 1.

Densoisporites sp.

Turma Triletes Zonales (Bennie and Kidston, 1886) Potonié, 1956.

Subturma Zonotriletes Waltz, 1938.

Infraturma Zonati Potonié and Kremp, 1954.

Subinfraturma Euzonati, Coronati Potonié, 1970.

Aequitriradites sp.

Anteturma Variegerminantes Potonié, 1970.

Turma Aletes Ibrahim, 1933, Kryptoperturates Potonié, 1966.

Subturma Azonaletes (Luber, 1938) Potonié and Kremp, 1954.

Infraturma Granulonapiti Cookson, 1947.

Araucariacites australis Cookson, 1947; Plate 4, Figure 2 (-) (7). Infraturma Circumpollini (Pflug, 1953) Klaus, 1960.

Classopollis brasiliensis Herngreen, 1975 (ex Herngreen, 1973); Plate 4, Figure $3(-)$ (6).

Classopollis sp.; Plate 4, Figures 4, 5 (-) (5)

Turma Plicates (Naumova, 1939) Potonié, 1960.

Subturma Polyplicates Erdtman, 1952 = Costates Potonié, 1970.
Infraturma Costati Potonié, 1970.

Ephedripites ambonoides Brenner, 1968; Plate 4, Figure 6.

Ephedripites dudarensis Deák, 1964 (-) (15).

Ephedripites montanaensis Brenner, 1968; Plate 4, Figure 7 (-) (12).

Ephedripites strigatus Brenner, 1968.

Ephedripites translucidus Deák and Combaz, 1967 (-) 16).

Ephedripites zaklinskaiae Azéma and Boltenhagen, 1974; Plate 4, Figure 8 (-) (14).

Ephedripites sp. 7 Herngreen, 1973; Plate 4, Figure 9 (-) (16).

Ephedripites sp. 8 Herngreen, 1973; Plate 4, Figure 10 (-) (10).

Gnetaceaepollenites boltenhagenii Dejax, 1985 (-) (11).

Gnetaceaepollenites barghoornii (Pocock, 1964) Lima, 1978; Plate 4, Figure $11(-)(9)$.

Gnetaceaepollenites jansonii (Pocock, 1964) Lima, 1978; Plate 4, Figure 12.

Steevesipollenites binodosus Stover, 1964 (-) (17).

Subturma Monocolpates et Zonocolpates Iversen and Troels-Smith, 1950. Infraturma Quasilevigati Potonié, 1970.

Cycadopites carpentieri (Delcourt and Sprumont, 1955) Singh, 1964 (-) (8). Infraturma Reticulati Pons, 1988.

Retimonocolpites sp. (-) (22).

Afropollis sp.; Plate 4, Figures 13-15.

Subturma Tricolpates, Triptyches Potonié, 1970.

Infraturma Isotricolpati Potonié, 1970.

Gemmatricolpites chmurae (Boltenhagen, 1976) Schrank and Ibrahim, 1995.

Subturma Tricolporates, Ptychotriporines Potonié, 1966.

Infraturma Tricolpolyporates Potonié, 1975.

Hexaporotricolpites emelianovi Boltenhagen, 1967; Plate 4, Figure 16 (-) (25).

Turma Poroses (Naumova, 1939) Potonié, 1960.

Subturma Monoporines Naumova, 1939.

Spheripollenites sp.

Subturma Triporines Potonié, 1960.

Triorites africaensis Jardiné and Magloire, 1965; Plate 5, Figs. 1, 2 (-) (23).

Triorites sp. Herngreen, 1973; Plate 5, Figure 3 (-) (-).

Subturma Polyporines Potonié, 1960.

Infraturma Periporati Potonié, 1975.

Cretacaeiporites sp.; Plate 5, Figure 4 (-) (24).

Varia

Elaterocolpites castelaini (Jardiné and Magloire, 1965) Jardiné, 1967; Plate 5, Figures 5, $6(-)$ (18).

Elaterosporites klaszi (Jardiné and Magloire, 1965) Jardiné, 1967, Plate 5, Figures 7, 8 .

Elaterosporites protensus (Stover, 1963) Jardiné, 1967; Plate 5, Figure 9 (-) (19).

Elaterosporites verrucatus (Jardiné and Magloire, 1965) Jardiné, 1967; Plate 5 , Figure 10.

Galeacornea causea Stover, 1963; Plate 5, Figure 11 (-) (21).

Reyrea polymorphus Herngreen, 1973; Plate 5, Figure 12. cf. Reyrea; Plate 5, Figure 13.

Incertae sedis (trilete spore or syncolpate pollen grain); Plate 5, Figure 14.

Chomotriletes sp. (acritarch).

\section{ACKNOWLEDGMENTS}

E. Masure, R. Rauscher, J. Dejax, M. Schuler, and B. Ferré wish to thank the ODP staff and J.-P. Bellier and J. Mascle for inviting them to participate in Leg 159. This research was supported in part 
by grants from ODP France and P. and M. Curie University (Micropaleontology Laboratory, Department of Sedimentary Geology, and URA-CNRS 1761) and Institut of Geology of Strasbourg. The authors thank. G.F.W. Herngreen, E. Schrank, L. Stokking, and M. Moullade for their comments and reviews of the manuscript.

\section{REFERENCES}

Alberti, G., 1959. Zur Kenntnis der Gattung Deflandrea Eisenack (Dinoflag.) in der Kreide und im Alttertiär Nord- und Mitteldeutschlands. Mitt. geol. Staatsinst. Hamburg, 28:93-105.

, 1961. Zur Kenntnis mesozoischer und alttertiärer Dinoflagellaten und Hystrichosphaerideen von Nord-und Mitteldeutschland sowie einigen anderen europäischen Gebieten. Palaeontographica B, 116:1-58.

Azéma, C., and Boltenhagen, E., 1974. Pollen du Crétacé moyen du Gabon attribué aux Ephedrales. Paleobiol. Contin., 5:1-38.

Basile, C., Brun, J.P., and Mascle, J., 1992. Structure et formation de la marge transformante de Côte d'Ivoire-Ghana: apports de la sismique réflexion et de la modélisation analogique. Bull. Soc. Geol. Fr., 163:207216.

Basile, C., Mascle, J., Popoff, M., Bouillin, J.P., and Mascle, G., 1993. The Côte d'Ivoire-Ghana transform margin: a marginal ridge structure deduced from seismic data. Tectonophysics, 222:1-19.

Below, R., 1981. Dinoflagellaten-Zysten aus dem oberen Hauterive bis unteren Cenoman Südwest-Marokkos. Palaeontographica B, 176:1-145.

, 1982. Scolochorate Zysten der Gonyaulacaceae (Dinophyceae) aus der Unterkreide Marokkos. Palaeontographica B, 182:1-51.

, 1987. Evolution und Systematik von Dinoflagellaten-Zysten aus der Ordnung Peridiniales, II. Cladopyxiaceae und Valvaeodiniaceae. Palaeontographica B, 206:1-135.

Bennie, J., and Kidston, R., 1886. On the occurrence of spores in the Carboniferous Formation of Scotland. Proc. R. Phys. Soc. Edinburgh, 9:82-117.

Boltenhagen, E., 1967. Pollen et spores du Crétacé supérieur du Gabon. Pollen et Spores, 9:335-355.

1976. Pollen et spores sénoniens du Gabon. Cah. Micropaleontol., 3:3-21.

, 1977. Microplancton du Crétacé Supérieur du Gabon. Paris (Cah. Paleontol., Ed. Cent. Nat. Rec. Sci.),1-150.

Brenner, G.J., 1963. The spores and pollen of the Potomac Group of Maryland. Maryland Dept. Geol., Min. Water Res. Bull., 27.

, 1968. Middle Cretaceous spores and pollen from northeastern Peru. Pollen Spores, 10:341-383.

Brinkhuis, H., and Zachariasse, W.J., 1988. Dinoflagellate cysts, sea level changes and planktonic foraminifers across the Cretaceous-Tertiary boundary at El Haria, northwest Tunisia. Mar. Micropaleontol., 13:153191.

Bujak, J.P., and Davies, E.H., 1983. Modern and fossil Peridiniineae. Contrib. Ser. Am. Assoc. Stratigr. Palynol., 13:1-203.

Clarke, R.F.A., Davey, R.J., Sarjeant, W.A.S., and Verdier, J.P., 1968. A note on the nomenclature of some Upper Cretaceous and Eocene dinoflagellate taxa. Taxon, 17:181-183.

Clarke, R.F.A., and Verdier, J.P., 1967. An investigation of microplankton assemblages from the Chalk of the Isle of Wight, England. Verh. K. Nederl. Akad. Wetensch., 24:1-96.

Cookson, I.C., 1947. Plant microfossils from the lignites of Kerguelen Archipelago. Brit. Aust. N.Z. Antarc. Res. Exped. 1929-1931 Rep. Ser. A, 2:127-142.

, 1956. Additional microplankton from Australian Late Mesozoic and Tertiary sediments. Aust. J. Mar. Freshwater Res., 7:183-191.

, 1965. Microplankton from the Paleocene Pebble Point Formation, south-western Victoria. Proc. R. Soc. Victoria, 78:137-141.

Cookson, I.C., and Eisenack, A., 1958. Microplankton from Australian and New Guinea Upper Mesozoic sediments. Proc. R. Soc. Victoria, 70:1979.

, 1962. Additional microplankton from Australian Cretaceous sediments. Micropaleontology, 8:485-507.

, 1965. Microplankton from the Dartmoor Formation, SW. Victoria. Proc. R. Soc. Victoria, 79:133-137.

, 1969. Some microplankton from two bores at Balcata, West Australia. J. R. Soc. W. Aust., 52:3-8.

Cookson, I.C., and Hughes, N.F., 1964. Microplankton from the Cambridge Greensand (mid-Cretaceous). Palaeontology, 7:37-59.
Corradini, D., 1973. Non-calcareous microplankton from the Upper Cretaceous of the northern Apennines. Boll. Soc. Paleontol. Ital., 11:119-197.

Couper, R.A., 1953. Upper Mesozoic and Cainozoic spores and pollen grains from New Zealand. Bull. N.Z. Geol. Surv. Palaeontol., 22:1-77.

1958. British Mesozoic microspores and pollen grains, a systematic and stratigraphic study. Palaeontographica B, 103:75-179.

Davey, R.J., 1969. Non calcareous microplankton from the Cenomanian of England, northern France and North America. Part 1. Bull. Brit. Mus. Nat. Hist. (Geol.), 17:1-180.

, 1970. Non-calcareous microplankton from the Cenomanian of England, northern France and North America, Part 2. Bull. Brit. Mus. Nat. Hist. (Geol.), 18:333-397.

, 1975. A dinoflagellate cyst assemblage from the Late Cretaceous of Ghana. Proc. 5th West Afr. Colloq. Micropaleontol., 7:150-173.

Davey, R.J., and Verdier, J.P., 1973. An investigation of microplankton assemblages from latest Albian (Vraconian) sediments. Rev. Esp. Micropaleontol., 5, 2:173-212.

_ 1976. A review of certain non-tabulate Cretaceous hystrichospherid dinocysts. Rev. Paleobot. Palynol., 22:307-335.

Davey, R.J., and Williams, G.L., 1966a. The genera Hystrichosphaera and Achomosphaera. In Davey, R.J., Downie, C., Sarjeant, W.A.S., and Williams, G.L., Studies on Mesozoic and Cainozoic dinoflagellate cysts. Bull. Brit. Mus. Nat. Hist. (Geol.), Suppl. 3:28-52.

, 1966b. The genus Hystrichosphaeridium and its allies. In Davey, R.J., Downie, C., Sarjeant, W.A.S., and Williams, G.L., Studies on Mesozoic and Cainozoic dinoflagellate cysts. Bull. Brit. Mus. Nat.Hist. (Geol.), Suppl. 3:53-106.

1969. Generic reallocations. In Davey, R.J., Downie, C., Sarjeant, W.A.S., and Williams, G.L. (Eds.), Appendix to "Studies on Mesozoic and Cainozoic dinoflagellate cysts.” Bull. Brit. Mus. Nat. Hist. (Geol.), Appendix to Suppl., 3:4-7.

Deák, M.H., 1963. Quelques spores striées de l'étage Aptien. Rev. Micropaleontol., 5:251-256.

, 1964. Contribution à l'étude palynologique du groupe d'argiles à Muniera de l'étage Aptien. Acta Bot. Hung., 10:95-126.

Deák, M.H., and Combaz, A., 1967. "Microfossiles organiques" du Wealdien et du Cénomanien dans un sondage de Charente-Maritime. Rev. Micropaleontol., 10:69-96.

Deflandre, G., 1935. Considération biologiques sur les microorganismes d'origine planctonique conservés dans les silex de la craie. Bull. Biol. Fr. Belg., 69:213-244.

_ 1936. Microfossiles des silex crétacés. Première partie. Généralités. Flagellés. Ann. Paleontol., 25:151-191.

Deflandre, G., and Cookson, I.C., 1955. Fossil microplankton from Australian late Mesozoic and Tertiary sediments. Aust. J. Mar. Freshwater Res., 6:242-313.

Dejax, J., 1985. Deux nouvelles espèces parmi le pollen et les spores du Crétacé inférieur du Congo, l'une rapportée aux Gnétophytes (ou Chlamydospermes), l'autre aux Schizéacées. 110ème Congr. Nat. Soc. Sav., Sci., 5: 87-98.

Delcourt, A., and Sprumont, G., 1955. Les spores et grains de pollen du Wealdien du Hainaut. Mem. Soc. Belge Geol. Paleontol. Hydrol., 5:1-73.

Dettmann, M.E., 1963. Upper Mesozoic microfloras from southeastern Australia. Proc. R. Soc. Victoria, 77:1-148.

Döring, H., 1964. Neue Sporengattungen und -arten aus dem Jura/KreideGrenzbereich Norddeutschlands. Mber. dt. Akad. Wiss. Berl., 6:37-45.

Doyle, J.A., Jardiné, J., and Doerenkamp, A., 1982. Afropollis, a new genus of early angiosperm pollen, with notes on the Cretaceous palynostratigraphy and paleoenvironments of northern Gondwana. Bull. Cent. Rech. Explor-Prod. Elf-Aquitaine, 6:39-117.

Drugg, W.S., 1967. Palynology of the Upper Moreno Formation (Late Cretaceous-Paleogene) Escarpado Canyon, California. Palaeontographica B, 120:1-71.

Dybowá, S., and Jachowicz, A., 1957. Microspores of the Upper Silesian coal measures. Inst. Geol. Pr., 23:1-328.

Ehrenberg, C.G., 1838. Über das Massenverhältnis der jetzt lebenden KieselInfusorien und über ein neues Infusorien-Conglomerat als Polierschiefer von Jastraba in Ungarn. Abh. K. Preuss. Akad. Wiss., 1836:109-135.

Eisenack, A., 1963. Cordosphaeridium n.g. ex Hystrichosphaeridium, Hystrichosphaeridae. Neues. Jahrb. Geol. Palaeontol. Abh., 118:260-265. 1965. Über einige Mikrofossilien des samländischen und norddeutschen Tertiärs. Neues. Jahrb. Geol. Palaeontol. Abh., 123:149-159. 
Erdtman, G., 1947. Suggestions for the classification of fossil and recent pollen grains and spores. Svensk Bot. Tidskr., 41:104-114.

, 1952. Pollen Morphology and Plant Taxonomy-Angiosperms: An Introduction to Palynology: Stockholm (Almqvist and Wiskell).

Evitt, W.R., Clarke, R.F.A., and Verdier, J.P., 1967. Dinoflagellate Studies III: Dinogymnium acuminatum n. gen., n. sp. (Maastrichtian) and other fossils formerly referable to Gymnodinium Stein. Stanford Univ. Publ. Geol. Sci., 10:3-27.

Fensome, R.A., Taylor, F.J.R, Norris, G., Sarjeant, W.A.S., Wharton, D.J., and Williams, G.L., 1993. A classification of living and fossil dinoflagellates. Micropaleontology, Spec. Publ., 7:1-351.

Fritsch, F.E., 1929. Evolutionary sequence and affinities among the Protophyta. Biol. Rev., 4:103-151.

Gerlach, E., 1961. Mikrofossilien aus dem Oligozän und Miozän Nordwestdeutschlands, unter besonderer Berücksichtigung der Hystrichosphären und Dinoflagellaten. Neues. Jahrb. Geol. Palaeontol. Abh., 112:143-228.

Gocht, H., 1959. Mikroplankton aus dem nordwestdeutschen Neokom (Teil II). Palaontol. Z., 33:50-89.

Haeckel, E., 1894. Systematische Phylogenie der Protisten und Pflanzen. Erster Teil des Entwarfs eines systematischen Phylogenie. Georg. Reimer, 15:1-400.

Hansen, J.M., 1977. Dinoflagellate stratigraphy and echinoid distribution in Upper Maastrichtian and Danian deposits from Denmark. Bull. Geol. Soc. Den., 26:1-26.

Herngreen, G.F.W., 1973. Palynology of Albian-Cenomanian strata of borehole 1-QS-1-MA, State of Maranhão, Brazil. Pollen et Spores, 15:515555 .

, 1975. Palynology of Middle and Upper Cretaceous strata in Brazil. Meded. Rijks Geol. Dienst, 26:39-91.

Herngreen, G.F.W., and Chlonova, A.F., 1981. Cretaceous microflora provinces. Pollen et Spores, 23:441-555.

Herngreen, G.F.W., Kedves, M., Rovnina, L.V., and Smirnova, S.B., 1996. Cretaceous palynofloral provinces: a review. In Jansonius, J., and McGregor, D.C. (Eds.), Palynology: Principles and Applications. AASP Foundation, College Station, TX, 3:1157-1188.

Hultberg, S.U., 1985. Systematic paleontology. In Hultberg, S.U. (Ed.), Dinoflagellate studies of the Upper Maastrichtian and Danian in southern Scandinavia. Dept. of Geol., Univ. Stockholm, 104-189.

Ibrahim, A., 1933. Sporenformen des Aegirhorizontes des Ruhrreviers [diss. th.]. Berlin.

Iversen, J., and Troels-Smith, J., 1950. Pollenmorfologiske definitioner og typer. Danm. Geol. Unders., 4:1-54.

Jain, K.P., 1977. Additional dinoflagellates and acritarchs from Grey Shale Member of Dalmiapuram Formation, south India. Palaeobotanist, 24:170-194.

Jain, K.P., and Millepied, P., 1973. Cretaceous microplankton from Senegal Basin, West Africa, Part I: Some new genera, species and combinations of dinoflagellates. Palaeobotanist, 20:22-32.

1975. Cretaceous microplankton from Senegal Basin, North West Africa. Part II: systematics and biostratigraphy. Geophytology, 5:126171

Jan du Chêne, R., 1988. Étude systématique des kystes de dinoflagellés de la Formation des Madeleines (Danien du Sénégal). Cahiers Micropal., 2: 147-174.

Jan du Chêne, R., and Adediran, S.A., 1985. Late Paleocene to Early Eocene dinoflagellates from Nigeria. Cah. Micropaleontol., 3:5-38.

Jardiné, S., 1967. Spores à expansions en forme d'élatères du Crétacé moyen d'Afrique occidentale. Rev. Palaeobot. Palynol., 1:235-258.

Jardiné, S., and Magloire, L., 1965. Palynologie et stratigraphie du Crétacé des bassins du Sénégal et du Côte d'Ivoire. Mem. Bur. Rech. Geol. Minieres, 32:187-245.

Kemp, E.M., 1970. Aptian and Albian miospores from southern England. Palaeontographica B, 131:73-143.

Kirsch, K.H., 1991. Dinoflagellaten-Zysten aus der Oberkreide des Helvetikums und Nordultrahelvetikums von Oberbayern. Münchner Geowiss. Abh., Reihe A, Geol. Palaeontol., 22:1-306.

Klaus, W., 1960. Sporen der karnischen Stufe der ostalpinen Trias. Geol. Jahrb. BA. Wien Sonderbd., 5:107-184.

Klumpp, B., 1953. Beitrag zur Kenntnis der Mikrofossilien des mittleren und oberen Eozän. Palaeontographica A, 103:307-406.

Lejeune-Carpentier, M., 1938. L'étude microscopique des silex. Areoligera: nouveau genre d'Hystrichosphaeridée (Sixième note). Ann. Soc. Geol. Belg., 62:163-174.
Lentin, J.K., and Vozzhennikova, T.F., 1990. Fossil dinoflagellates from the Jurassic, Cretaceous and Paleogene deposits of the USSR: a re-study. Am. Assoc. Stratigr. Palynol. Contrib. Ser., 23:1-22.

Lentin, J.K., and Williams, G.L., 1973. Fossil dinoflagellates: index to genera and species. Supplement 1. Pap-Geol. Surv. Can., 73-42:1-176. , 1976. A monograph of fossil peridinioid cysts. Bedford Inst. Oceanogr. Rep. Ser., BI-75-16.

, 1980. Dinoflagellate provincialism, with emphasis on Campanian Peridiniaceans. Am. Assoc. Stratigr. Palynol. Contrib. Ser., 7:1-46.

, 1981. Fossil dinoflagellates: index to genera and species, 1981 edition. Geol. Surv. Can., Rep. Ser. BI-R-81-12:1-345.

, 1987. Status of the fossil dinoflagellate genera Ceratiopsis Vozzhennikova 1963 and Cerodinium Vozzhennikova 1963 emend. Palynology, 11:113-116.

, 1989. Fossil dinoflagellates: index to genera and species. Am. Assoc. Stratigr. Palynol. Contrib. Ser., 20:1-473.

, 1993. Fossil dinoflagellates: index to genera and species, 1989 edition. Am. Assoc. Stratigr. Palynol. Contrib. Ser., 28:1-856.

Lima, M.R., 1978. Palinología da Formação Santana (Cretáceo do Nordeste do Brasil) [Tese Doutoramento]. Inst. Geociênc., Univ. São Paulo.

Loeblich, A.R., and Loeblich, A.R., III, 1966. Index to genera, subgenera, and sections of the Pyrrhophyta. Stud. Trop. Oceanogr., 3:1-94.

Londeix, L., Pourtoy, D., and Fenton, J.P.G., 1996. The presence of Dinogymnium (Dinophyceae) in Lower Cretaceous sediments from the northwest Tethys (southeast France and western Switzerland) and Gulf of Mexico areas; stratigraphic and systematic consequences. Rev. Palaeobot. Palynol., 92:367-382.

Luber, A.A., 1938. Classification and stratigraphic value of some carboniferous coal deposits in the U.S.S.R. In Luber, A.A., and Waltz, J.E. (Eds.), Trans. Centr. Geol. Prosp. Inst., 105:1-45. (in Russian)

Malloy, R.E., 1972. An Upper Cretaceous dinoflagellate cyst lineage from Gabon, West Africa. Geosciences and Man, 4:57-65.

Mantell, G.A., 1850. A Pictorial Atlas of Fossil Remains, Consisting of Coloured Illustrations Selected from Parkinson's "Organic Remains of a Former World," and Artis's "Antediluvian Phytology:" London (Henry G. Bohn).

, 1854. The Medals of Creation; or, First Lessons in Geology and the Study of Organic Remains (2nd ed.): London (Henry G. Bohn).

Mascle, J., and Blarez, E., 1987. Evidence for transform margin evolution from the Côte d'Ivoire-Ghana continental margin. Nature, 326:378-381.

Mascle, J., Lohmann, G.P., Clift, P.D., et al., 1996. Proc. ODP, Init. Repts., 159: College Station, TX (Ocean Drilling Program).

Masure, E., 1988. Berriasian to Aptian dinoflagellate cysts from the Galicia Margin, offshore Spain, Sites 638 and 639, ODP Leg 103. In Boillot, G., Winterer, E.L., et al., Proc. ODP, Sci. Results, 103: College Station, TX (Ocean Drilling Program), 433-444.

Masure, E., Tea, J., and Yao, R., 1996. The dinoflagellate Andalusiella; emendation of the genus, revision of species, A. ivoirensis Masure, Tea and Yao, sp. nov. Rev. Palaeobot. Palynol., 91:171-186.

May, F.E., 1980. Dinoflagellate cysts of the Gymnodiniaceae, Peridiniaceae and Gonyaulacaceae from the Upper Cretaceous Monmouth Group, Atlantic highlands, New Jersey. Palaeontographica B, 172:10-116.

McMinn, A., 1988. Outline of a Late Cretaceous dinoflagellate zonation of northwestern Australia. Alcheringa, 12:137-156.

Morgenroth, P., 1966. Mikrofossilien und Konkretionen des nordwesteuropäischen Untereozäns. Palaeontogr. Abt. B, 119:1-53.

1968. Zur Kenntnis der Dinoflagellaten und Hystrichosphaeridien des Danien. Geol. Jahrb., 86:533-587.

Naumova, S.N., 1939. Spores and pollen of coals of the U.S.S.R. Rep. Int. Geol. Congr., 17th Sess. U.S.S.R., 1:353-364.

Norvick, M.S., and Burger, D., 1976. Palynology of the Cenomanian of Bathurst Island, Northern territory, Australia. Bull. Bur. Miner. Resour. Geol. Geophys., 151:1-169.

Pflug, H.D., 1953. Zur Enstehung und Entwicklung des angiospermiden Polens in der Erdgeschichte. Palaeontographica B, 95:60-171.

Pocock, S.A.J., 1964. Pollen and spores of the Chlamydospermidae and Schizaeaceae from Upper Manville strata of the Saskatoon area of Saskatchewan. Grana Palynol., 5:129-209.

, 1970. Palynology of the Jurassic sediments of western Canada, 1. Terrestrial species. Palaeontographica B, 130:12-136.

Pons, D., 1988. Le Mésozoïque de Colombie, Macroflores et Microflores: Paris (Cah. Paleontol., Ed. Cent. Nat. Rec. Sci.), 1-168.

Potonié, R., 1956. Synopsis der Gattungen der Sporae dispersae I: Sporites. Beih. Geol. Jahrb., 23:1-103. 
1960. Synopsis der Gattungen der Sporae dispersae. III Teil: Nachträge Sporites, Fortsetzung Pollenites, mit Generalregister zu Teil IIII. Beih. Geol. Jahrb., 39:1-189.

_ 1966. Synopsis der Gattungen der Sporae dispersae. IV. Nachträge zu allen Gruppen (Turmae). Beih. Geol. Jahrb., 72:1-244.

, 1970. Synopsis der Gattungen der Sporae dispersae. V Teil: Nachträge zu allen Gruppen (Turmae). Beih. Geol. Jahrb., 87:1-222. $25: 1-282$

Potonié, R., and Kremp, G., 1954. Die Gattungen der paläozoischen Sporae dispersae und ihre Stratigraphie. Geol. Jahrb., 69:111-194.

Powell, A.J., 1992. Dinoflagellate cysts of the Tertiary System. In Powell, A.J. (Ed.), A Stratigraphic Index of Dinoflagellate Cysts: London (Chapman and Hall), 155-251.

Regali, M.S.P., 1987. O gênero Afropollis, Doyle, Jardiné et Doerenkamp, 1982 e sua distribuição no Cretáceo do Brasil. Anais X Congr. Bras. Paleontol., 2:625-635.

Reinsch, P.F., 1881. Neue Untersuchungen über die Mikrostruktur der Steinkohle: Leipzig.

Riegel, W., 1974. New forms of organic-walled microplancton from an Upper Cretaceous assemblage in southern Spain. Rev. Esp. Micropaleontol., 6:347-353.

Riegel, W., and Sarjeant, W.A.S., 1982. Dinoflagellate cysts from the Upper Cretaceous of southern Spain: new morphological and taxonomic observations. Neues Jahrb. Geol. Palaeontol. Abh., 162:286-303.

Sarjeant, W.A.S., 1966. Further dinoflagellate cysts from the Speeton Clay. In Davey, R.J., Downie, C., Sarjeant, W.A.S., and Williams, G.L. (Ed.), Studies on Mesozoic and Cainozoic dinoflagellate cysts. Bull. Brit. Mus. Nat. Hist. (Geol.), Suppl. 3:199-214.

- 1970. The genus Spiniferites Mantell, 1850 (Dinophyceae). Grana, 10:74-78.

, 1981. A restudy of some dinoflagellate cyst holotypes in the University of Kiel Collections, II. The Eocene holotypes of Barbara Klumpp (1953); with a revision of the genus Cordosphaeridium Eisenack, 1963. Meyniana, 34:97-132.

Schrank, E., 1987. Palaeozoic and Mesozoic palynomorphs from northeast Africa (Egypt and Soudan) with special reference to Late Cretaceous pollen and dinoflagellates. Berl. Geowiss. Abh A, 75:249-310.

Schrank, E., and Ibrahim, M.I.A., 1995. Cretaceous (Aptian-Maastrichtian) palynology of foraminifera-dated wells (KRM-1, AG-18) in northwestern Egypt. Berl. Geowiss. Abh. A, 177:1-44.

Shipboard Scientific Party, 1996a. Site 959. In Mascle, J., Lohmann, G.P., Clift, P.D., et al., Proc. ODP, Init. Repts., 159: College Station, TX (Ocean Drilling Program), 65-150.

, 1996b. Site 960. In Mascle, J., Lohmann, G.P., Clift, P.D., et al., Proc. ODP, Init. Repts., 159: College Station, TX (Ocean Drilling Program), 151-215.

, 1996c. Site 961. In Mascle, J., Lohmann, G.P., Clift, P.D., et al., Proc. ODP, Init. Repts., 159: College Station, TX (Ocean Drilling Program), 217-249.

, 1996d. Site 962. In Mascle, J., Lohmann, G.P., Clift, P.D., et al., Proc. ODP, Init. Repts., 159: College Station, TX (Ocean Drilling Program), 251-294.

Singh, C., 1964. Microflora of the Lower Cretaceous Mannville Group, EastCentral Alberta. Bull. Res. Counc. Alberta, 15:1-239.

- 1983. Cenomanian microfloras of the Peace River area, NW Alberta. Bull. Alberta Geol. Surv., 44:1-322.

Slimani, H., 1995. Les dinokystes des craies du Campanien au Danien à Hallembaye et Turnhout (Belgique) et à Beutenaken (Pays-Bas): Biostratigraphie et Systématique [thèse doctorat]. Univ. Gent.

Soncini, M.J., 1992. Three new dinoflagellate cysts from the Moroccan Paleocene-Eocene phosphates. Rev. Palaeobot. Palynol., 70:325-338.

Srivastava, S.K., 1975. Microspores from the Fredericksburg Group (Albian) of the southern United States. Paleobiol. Continent., 6:1-119.
Stanley, E.A., 1965. Upper Cretaceous and Paleocene plant microfossils and Paleocene dinoflagellates and hystrichosphaerids from northwestern South Dakota. Bull. Am. Paleontol., 49:179-384.

Stone, J.F., 1973. Palynology of the Almond Formation (Upper Cretaceous) Rock Springs Uplift, Wyoming. Bull. Am. Paleontol., 64:1-135.

Stover, L.E., 1963. Some Middle Cretaceous palynomorphs from West Africa. Micropaleontology, 9:85-94.

1964. Cretaceous ephedroid pollen from West Africa. Micropaleontology, 10:145-156.

Stover, L.E., and Evitt, W.R., 1978. Analyses of pre-Pleistocene organicwalled dinoflagellates. Stanford Univ. Publ. Geol. Sci., 15:1-300.

Stover, L.E., and Helby, R., 1987. Some Australian Mesozoic microplankton index species. In Jell, P.A. (Ed.), Studies in Australian Mesozoic Palynology. Mem. Assoc. Australas. Palaeontol., 4:101-134.

Stover, L.E., and Williams, G.L., 1987. Analyses of Mesozoic and Cenozoic organic-walled dinoflagellates 1977-1985. Am. Assoc. Stratigr. Palynol. Contrib. Ser., 18:1-243.

Vozzhennikova, T.F., 1963. Klass Peridineae (Dinoflagellateae). Peridinei, ili dinoflagellaty. In Kiseleva, A., Vachrameeva, V.A., Radchenki, G.P., and Tachmadzhana, A.L. (Eds.), Tip Pyrrophyta. Pirrofitovye Vodorosli. In Vodorosli, Mochoobraznie, Psilofitovie, Planovidnie, Chlenistotebelnie, Paporotniki Osnovy, Paleontologii, 14:171-186.

, 1967. Iskopaemye peridinei yurskikh, melovykh i paleogenovykh otlozheniy SSSR. (Fossil peridinians of the Jurassic, Cretaceous and Paleogene deposits of the U.S.S.R.). Moskva, Izd. Nauka, 1-347.

Waltz, J.E., 1938. Classification and stratigraphic value of some carboniferous coal deposits in the U.S.S.R. In Luber, A.A., and Waltz, J.E. (Eds.), Trans. Centr. Geol. Prosp. Inst., 105:1-45. (in Russian)

Wetzel, O., 1933a. Die in organischer Substanz erhaltenen Mikrofossilien des baltischen Kreide-Feuersteins mit einem sediment-petrographischen und stratigraphischen Anhang. Palaeontographica A, 77:141-188.

, 1933b. Die in organischer Substanz erhaltenen Mikrofossilien des baltischen Kreide-Feuersteins mit einem sediment-petrographischen und stratigraphischen Anhang. Palaeontographica A, 78:1-110.

White, H.H., 1842. On fossil Xanthidia. Microscopical J., London, 11:3540 .

Williams, G.L., 1978. Palynological biostratigraphy, Deep Sea Drilling Project, Sites 367 and 370. In Lancelot, Y., Seibold, E., et al., Init. Repts. DSDP, 38-41 (Suppl.): Washington (U.S. Govt. Printing Office), 783815.

Williams, G.L., and Bujak, J.P., 1985. Mesozoic and Cenozoic dinoflagellates. In Bolli, H.M, Saunders, J.B., and Perch-Nielsen, K. (Eds.), Plankton Stratigraphy: Cambridge (Cambridge Univ. Press), 847-964.

Williams, G.L., and Downie, C., 1966. Further dinoflagellate cysts from the London Clay. In Davey, R.J., Downie, C., Sarjeant, W.A.S., and Williams, G.L. (Eds.), Studies on Mesozoic and Cainozoic Dinoflagellate Cysts. Bull. Brit. Mus. Nat. Hist. (Geol.), Suppl. 3:215-235.

Wrenn, J.H., 1988. Differentiating species of the dinoflagellate cyst genus Nematosphaeropsis Deflandre and Cookson 1955. Palynology, 12:129150.

Wrenn, J.H., and Hart, G.F., 1988. Paleogene dinoflagellate cyst biostratigraphy of Seymour Island, Antarctica. Mem.-Geol. Soc. Am., 169:321447.

Yun, H.-S., 1981. Dinoflagellaten aus der Oberkreide (Santon) von Westfalen. Palaeontographica B, 177:1-89.

Date of initial receipt: 16 September 1996

Date of acceptance: 6 February 1997

Ms 159SR-040 
APPENDIX

List of all studied samples.

\begin{tabular}{|c|c|}
\hline $\begin{array}{l}\text { Core, section, } \\
\text { interval }(\mathrm{cm})\end{array}$ & $\begin{array}{l}\text { Depth } \\
\text { (mbsf) }\end{array}$ \\
\hline \multicolumn{2}{|l|}{ 159-959D- } \\
\hline $44 \mathrm{R}-6,60-62$ & 828.70 \\
\hline $44 \mathrm{R}-6,61-63$ & 828.71 \\
\hline $44 \mathrm{R}-6,83-85$ & 828.93 \\
\hline $45 \mathrm{R}-1,11-16$ & 831.71 \\
\hline $45 \mathrm{R}-1,34-39$ & 831.94 \\
\hline $46 \mathrm{R}-1,95-100$ & 842.25 \\
\hline $46 \mathrm{R}-2,18-23$ & 842.48 \\
\hline $47 \mathrm{R}-1,35-37$ & 851.25 \\
\hline $47 \mathrm{R}-1,79-82$ & 851.69 \\
\hline $48 \mathrm{R}-1,8-11$ & 860.68 \\
\hline $48 \mathrm{R}-3,65-68$ & 864.25 \\
\hline $49 \mathrm{R}-1,139-142$ & 871.59 \\
\hline $49 \mathrm{R}-4,133-137$ & 876.03 \\
\hline $50 \mathrm{R}-5,98-100$ & 886.88 \\
\hline 50R-6, $2-5$ & 886.92 \\
\hline $51 \mathrm{R}-3,10-13$ & 892.30 \\
\hline $51 \mathrm{R}-4,8-11$ & 893.78 \\
\hline $52 \mathrm{R}-3,10-13$ & 901.90 \\
\hline $52 \mathrm{R}-3,129-132$ & 903.09 \\
\hline $53 \mathrm{R}-3,68-71$ & 910.97 \\
\hline $53 \mathrm{R}-6,18-20$ & 914.97 \\
\hline $54 \mathrm{R}-2,1-3$ & 919.61 \\
\hline $54 \mathrm{R}-2,97-99$ & 920.57 \\
\hline $55 \mathrm{R}-3,83-85$ & 930.39 \\
\hline $55 \mathrm{R}-4,94-97$ & 932.00 \\
\hline 56R-1, 101-103 & 938.41 \\
\hline $56 \mathrm{R}-4,60-62$ & 942.50 \\
\hline $57 \mathrm{R}-11,31-134$ & 948.41 \\
\hline 57R-2, 12-15 & 948.72 \\
\hline $57 \mathrm{R}-4,114-117$ & 952.74 \\
\hline $58 \mathrm{R}-3,93-96$ & 960.03 \\
\hline $58 \mathrm{R}-3,123-126$ & 960.33 \\
\hline $59 \mathrm{R}-4,118-123$ & 972.18 \\
\hline 59R-5, 39-44 & 972.89 \\
\hline $60 \mathrm{R}-1,56-59$ & 976.66 \\
\hline $60 \mathrm{R}-2,8-11$ & 977.68 \\
\hline $60 \mathrm{R}-4,16-19$ & 980.76 \\
\hline $60 \mathrm{R}-4,58-61$ & 981.18 \\
\hline $62 \mathrm{R}-1,76-78$ & 996.16 \\
\hline $62 \mathrm{R}-3,65-70$ & 999.05 \\
\hline $63 \mathrm{R}-2,89-91$ & 1007.39 \\
\hline $63 R-5,91-93$ & 1011.91 \\
\hline $64 \mathrm{R}-1,92-95$ & 1015.62 \\
\hline $64 \mathrm{R}-4,89-92$ & 1020.09 \\
\hline $65 \mathrm{R}-2,27-30$ & 1025.87 \\
\hline $65 \mathrm{R}-4,8-11$ & 1028.68 \\
\hline $66 \mathrm{R}-1,33-37$ & 1034.03 \\
\hline $66 \mathrm{R}-3,40-43$ & 1037.10 \\
\hline $67 \mathrm{R}-2,57-61$ & 1045.37 \\
\hline $67 \mathrm{R}-2,91-95$ & 1045.71 \\
\hline $72 \mathrm{R}-2,30-35$ & 1093.00 \\
\hline $72 \mathrm{R}-2,85-90$ & 1093.55 \\
\hline $75 \mathrm{R}-1,20-24$ & 1120.40 \\
\hline $75 \mathrm{R}-1,134-138$ & 1121.54 \\
\hline 76R-2, 13-16 & 1131.43 \\
\hline $76 \mathrm{R}-2,26-30$ & 1131.56 \\
\hline \multicolumn{2}{|l|}{ 159-960A- } \\
\hline $38 \mathrm{R}-2,70-75$ & 340.40 \\
\hline $38 \mathrm{R}-2,139-142$ & 341.09 \\
\hline $40 \mathrm{R}-2,44-47$ & 350.24 \\
\hline $40 \mathrm{R}-2,80-83$ & 350.60 \\
\hline $41 \mathrm{R}-2,9-12$ & 352.59 \\
\hline 41R-?, $65-68$ & 353.15 \\
\hline $42 \mathrm{R}-1,63-66$ & 354.13 \\
\hline $42 \mathrm{R}-1,137-140$ & 354.87 \\
\hline $43 \mathrm{R}-1,55-59$ & 358.05 \\
\hline $43 \mathrm{R}-2,104-108$ & 360.04 \\
\hline 44R-1, 104-107 & 363.34 \\
\hline $45 \mathrm{R}-1,4-7$ & 367.24 \\
\hline $45 \mathrm{R}-3,20-24$ & 370.40 \\
\hline
\end{tabular}

\begin{tabular}{|c|c|}
\hline $\begin{array}{l}\text { Core, section, } \\
\text { interval }(\mathrm{cm})\end{array}$ & $\begin{array}{l}\text { Depth } \\
\text { (mbsf) }\end{array}$ \\
\hline $\begin{array}{l}46 \mathrm{R}-1,22-26 \\
46 \mathrm{R}-3,123-128 \\
47 \mathrm{R}-2,25-29 \\
47 \mathrm{R}-2,67-70 \\
47 \mathrm{R}-\mathrm{CC}, 3-8 \\
48 \mathrm{R}-1,126-130 \\
50 \mathrm{R}-1,52-56 \\
\text { 50R-3, } 110-114 \\
\text { 52R-2, 29-32 } \\
\text { 53R-1, 90-93 } \\
\text { 54R-1, 92-96 } \\
\text { 54R-2, 78-82 } \\
\text { 55R-1, 124-128 } \\
\text { 56R-1, 42-45 } \\
\text { 56R-?, 102-106 } \\
\text { 57R-1, 47-51 } \\
\text { 57R-1, 135-138 } \\
\text { 58R-1, 104-107 } \\
\text { 58R-3, 33-36 } \\
\text { 59R-1, 62-65 } \\
\text { 59R-1, 129-133 } \\
\text { 61R-1, 8-11 }\end{array}$ & $\begin{array}{l}372.02 \\
376.03 \\
378.55 \\
378.97 \\
379.21 \\
380.56 \\
391.62 \\
395.20 \\
399.09 \\
404.20 \\
414.02 \\
415.38 \\
419.04 \\
423.22 \\
423.82 \\
427.87 \\
428.75 \\
433.44 \\
435.50 \\
437.62 \\
439.55 \\
446.28\end{array}$ \\
\hline $\begin{array}{l}159-960 \mathrm{C}- \\
25 \mathrm{X}-1,48-52 \\
26 \mathrm{X}-2,44-49\end{array}$ & $\begin{array}{l}333.68 \\
345.14\end{array}$ \\
\hline $\begin{array}{l}\text { 159-961A- } \\
\text { 22R-2, 17-20 } \\
\text { 23R-1, 39-44 } \\
\text { 23R-1, 60-64 } \\
\text { 24R-1, 53-56 } \\
\text { 24R-1, 110-113 } \\
\text { 25R-1, 100-103 } \\
\text { 25R-2, 8-11 } \\
\text { 26R-1, 13-15 } \\
\text { 26R-1, 62-64 } \\
\text { 27R-1, 9-11 } \\
\text { 28R-1, 1-3 } \\
\text { 28R-2, 43-45 } \\
\text { 29R-2, 17-21 } \\
\text { 29R-2, 52-56 } \\
\text { 30R-2, 36-40 } \\
\text { 30R-2, 53-57 } \\
\text { 31R-1, 34-38 } \\
\text { 31R-1, 120-23? } \\
\text { 32R-1, 96-99 } \\
\text { 32R-1, 116-19? } \\
\text { 33R-1, 47-54 } \\
\text { 34R-1, 123-127 } \\
\text { 34R-2, 82-87 } \\
\text { 35R-1, 3-6 } \\
\text { 35R-1, 14-19 }\end{array}$ & $\begin{array}{l}198.07 \\
206.49 \\
206.70 \\
216.23 \\
216.80 \\
226.50 \\
227.08 \\
235.73 \\
236.22 \\
245.79 \\
255.31 \\
257.23 \\
266.57 \\
266.92 \\
276.36 \\
276.53 \\
284.54 \\
285.40 \\
294.76 \\
294.96 \\
299.97 \\
304.73 \\
305.82 \\
308.23 \\
308.34\end{array}$ \\
\hline $\begin{array}{l}\text { 159-961B- } \\
\text { 2R-1, 22-25 } \\
\text { 2R-1, 120-23 } \\
\text { 3R-1, 32-35 } \\
\text { 3R-1, 100-103 } \\
\text { 4R-2, 60-64 } \\
\text { 4R-2, 100-104 } \\
\text { 5R-2, 142-145 } \\
\text { 6R-2, 55-57 } \\
\text { 6R-2, 112-115 } \\
\text { 7R-2, 29-31 } \\
\text { 7R-3, 45-47 } \\
\text { 8R-1, 25-28 } \\
\text { 8R-2, 25-28 } \\
\text { 9R-1, 15-18 } \\
\text { 9R-2, 84-86 } \\
\text { 10R-3, 108-113 } \\
\text { 10R-3, 117-122 } \\
\text { 11R-1, 9-12 } \\
\text { 11R-1, 55-58 }\end{array}$ & $\begin{array}{l}226.22 \\
227.20 \\
236.32 \\
237.00 \\
262.00 \\
262.40 \\
270.42 \\
276.55 \\
277.12 \\
285.99 \\
287.15 \\
294.05 \\
295.55 \\
303.65 \\
305.84 \\
317.28 \\
317.37 \\
317.49 \\
317.95\end{array}$ \\
\hline
\end{tabular}

\begin{tabular}{|c|c|}
\hline $\begin{array}{l}\text { Core, section, } \\
\text { interval }(\mathrm{cm})\end{array}$ & $\begin{array}{l}\text { Depth } \\
\text { (mbsf) }\end{array}$ \\
\hline $\begin{array}{l}\text { 159-961B- } \\
\text { 12R-1, 49-51 } \\
\text { 12R-1, 87-90 } \\
\text { 13R-2, 26-28 } \\
\text { 13R-CC, } 9-12 \\
\text { 15R-1, 57-59 } \\
\text { 15R-C, 6-8 } \\
\text { 16R-2, 117-120 } \\
\text { 16R-3, 16-19 } \\
\text { 17R-1, 12-16 } \\
\text { 17R-1, 55-59 }\end{array}$ & $\begin{array}{l}322.89 \\
323.27 \\
333.86 \\
335.30 \\
351.97 \\
354.01 \\
358.37 \\
358.86 \\
360.82 \\
361.25\end{array}$ \\
\hline $\begin{array}{l}\text { 159-962B- } \\
8 \mathrm{H}-2,30-35 \\
8 \mathrm{H}-5,44-49 \\
9 \mathrm{H}-3,69-74 \\
9 \mathrm{H}-4,65-70\end{array}$ & $\begin{array}{l}66.30 \\
70.94 \\
77.69 \\
79.15\end{array}$ \\
\hline $\begin{array}{l}\text { 159-962C- } \\
\text { 1R-1, 5-8 } \\
\text { 1R-CC, 7-9 }\end{array}$ & $\begin{array}{l}73.05 \\
73.29\end{array}$ \\
\hline $\begin{array}{l}\text { 159-962D- } \\
\text { 6R-1, 36-38 } \\
\text { 9R-1, 126-130 } \\
\text { 9R-5, 95-99 } \\
\text { 10R-1, 14-17 } \\
\text { 10R-2, 74-77 } \\
\text { 12R-3, 40-43 } \\
\text { 12R-5, 68-71 } \\
\text { 13R-1, 57-59 } \\
\text { 13R-2, 78-82 } \\
\text { 15R-CC, 13-16 } \\
\text { 16R-2, 100-103 } \\
\text { 16R-3, 95-98 } \\
\text { 18R-2, 66-70 } \\
\text { 18R-2, 125-129 } \\
\text { 19R-2, 39-42 } \\
\text { 19R-2, 45-48 } \\
\text { 20R-2, 79-84 } \\
\text { 20R-3, 8-14 } \\
\text { 21R-2, 3-6 } \\
\text { 21R-2, 34-38 } \\
\text { 22R-1, 19-22 } \\
\text { 23R-1, 50-53 } \\
\text { 23R-1, 115-120 } \\
\text { 24R-2, 119-123 } \\
\text { 24R-2, 146-150 } \\
\text { 25R-1, 33-37 } \\
\text { 25R-1, 108-110 } \\
\text { 26R-1, 90-93 } \\
\text { 26R-2, 120-124 } \\
\text { 27R-1, 40-44 } \\
\text { 27R-2, 114-117 } \\
\text { 28R-1, 8-10 } \\
\text { 28R-1, 63-66 } \\
\text { 29R-1, 83-87 } \\
\text { 29R-2, 37-40 } \\
\text { 30R-1, 40-42 } \\
\text { 30R-2, 18-21 } \\
\text { 31R-1, 88-91 } \\
\text { 31R-2, 28-31 } \\
\text { 32R-1, 30-33 } \\
\text { 33R-1, 79-82 } \\
\text { 33R-CC, 0-3 } \\
\text { 34R-2, 70-73 } \\
\text { 34R-2, 130-133 } \\
\text { 35R-1, 134-137 } \\
\text { 35R-2, 0-3 } \\
\text { 36R-1, 146-149 } \\
\text { 36R-2, 19-22 } \\
\text { 37R-1, 142-145 } \\
\text { 37R-4, 26-30 } \\
\text { 37R-4, 49-52 }\end{array}$ & $\begin{array}{l}123.76 \\
153.66 \\
159.35 \\
162.14 \\
164.24 \\
184.70 \\
187.98 \\
191.57 \\
193.28 \\
210.43 \\
222.50 \\
223.95 \\
241.26 \\
241.85 \\
250.69 \\
250.75 \\
260.69 \\
261.48 \\
269.35 \\
269.66 \\
277.89 \\
287.80 \\
288.45 \\
299.69 \\
299.96 \\
302.33 \\
303.08 \\
307.50 \\
309.30 \\
311.70 \\
313.94 \\
316.38 \\
316.93 \\
326.83 \\
327.87 \\
336.00 \\
337.28 \\
346.18 \\
347.08 \\
355.20 \\
365.39 \\
366.83 \\
371.50 \\
372.10 \\
375.64 \\
375.80 \\
385.36 \\
385.59 \\
389.92 \\
393.26 \\
393.49\end{array}$ \\
\hline
\end{tabular}



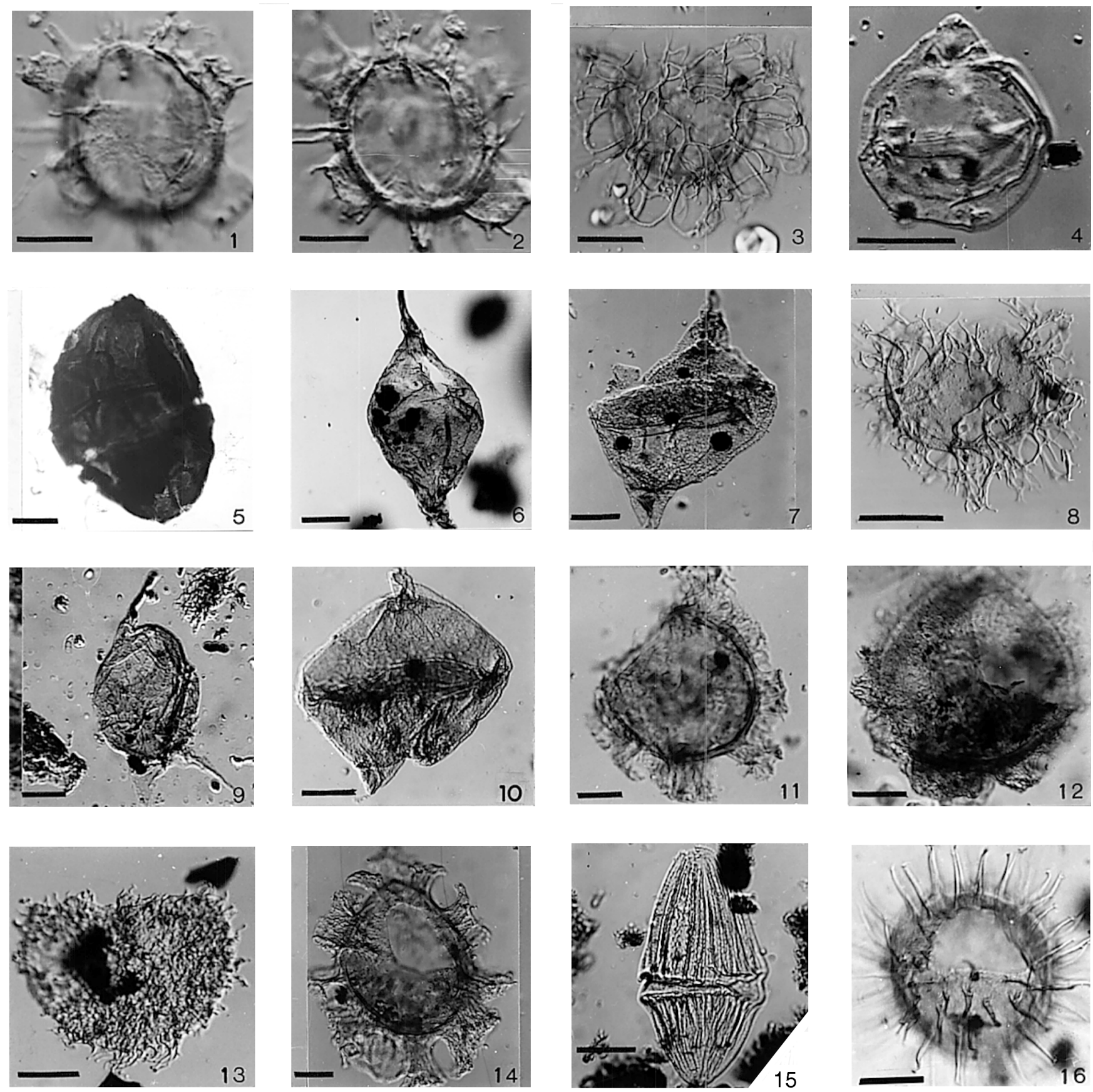

Plate 1. Photomicrographs of dinoflagellate cysts. Scale bar $=20 \mu \mathrm{m}$. 1, 2. Achilleodinium bianii, total length $64 \mu \mathrm{m}$, Sample 159-959D-45R-1, 34-39 cm, $831.94 \mathrm{mbsf}$, slide 2: YZ 37; (1) interior view of dorsal face, precingular archeopyle (3'), (2) optical section, focus on tubules of distal ends of processes. 3. Adnatosphaeridium multispinosum, total diameter $92 \mu \mathrm{m}$, Sample 159-959D-44R-6, 60-62 cm, $828.70 \mathrm{mbsf}$, slide 2: R 41, general view. 4. Alterbidinium varium, length $44 \mu \mathrm{m}$, Sample 159-959D-53R-6, 18-20 cm, $914.97 \mathrm{mbsf}$, slide 1: K 34, optical section. 5. Andalusiella ivoirensis, central body length 100 $\mu \mathrm{m}$, Sample 159-959D-57R-4, 114-117 cm, 952.74 mbsf, slide 1: FG 32, focus on the parasutural septa of the black central body, cyst with broken horns. 6 . Andalusiella mauthei subsp. mauthei, length $160 \mu \mathrm{m}$, Sample 159-959D-60R-4, 58-61 cm, $981.18 \mathrm{mbsf}$, slide 1: P42, general view. 7. Andalusiella rhomboides, central body diameter $76 \mu \mathrm{m}$, Sample 159-959D-54R-2, 97-99 cm, $920.57 \mathrm{mbsf}$, slide 1: U 28-2, general view, folded specimen. 8. Areoligera volata, total diameter $92 \mu \mathrm{m}$, Sample 159-959D-44R-6, 60-62 cm, $828.70 \mathrm{mbsf}$, slide 2: O 16-17, dorsal face, high focus. 9. Cerodinium diebelii, central body length $72 \mu \mathrm{m}$, Sample 159-959D- 57R-2, 12-15 cm, 948.72 mbsf, slide 2: ST 26, general view. 10. Cerodinium granulostriatum, length $96 \mu \mathrm{m}$, Sample $159-$ 959D-57R-4, 114-117 cm, 952.74 mbsf, slide 1: V 34-2, general view. 11. Cordosphaeridium cf. inodes, total diameter 98 $\mu$ m, Sample 159-959D-51R-4, 8$11 \mathrm{~cm}, 893.78$ mbsf, slide 1: J 43-3, optical section. 12. Cordosphaeridium varians, total length $96 \mu \mathrm{m}$, Sample 159-959D-53R-6, 18-20 cm, $914.97 \mathrm{mbsf}$, slide 1: O 46, focus on loose processes. 13. Cyclonephelium deconinckii, central body diameter $76 \mu \mathrm{m}$, Sample 159-959D-64R-1, 92-95 cm, 1015.62 mbsf, slide 1: F 42, general view. 14. Danea californica, length $135 \mu \mathrm{m}$, Sample 159-959D-51R-4, 8-11 cm, 893.78 mbsf, slide 1: M 34, dorsal face. 15. Dinogymnium denticulatum, length $80 \mu \mathrm{m}$, Sample 159-959D-66R-3, 40-43 cm, $1037.10 \mathrm{mbsf}$, slide 2: TU 42, general view. 16. Exochosphaeridium bifidum, length $81 \mu \mathrm{m}$, Sample 159-959D-46R-1, 95-100 cm, $842.25 \mathrm{mbsf}$, slide 1: Z 25, focus on processes and precingular archeopyle (3'). 

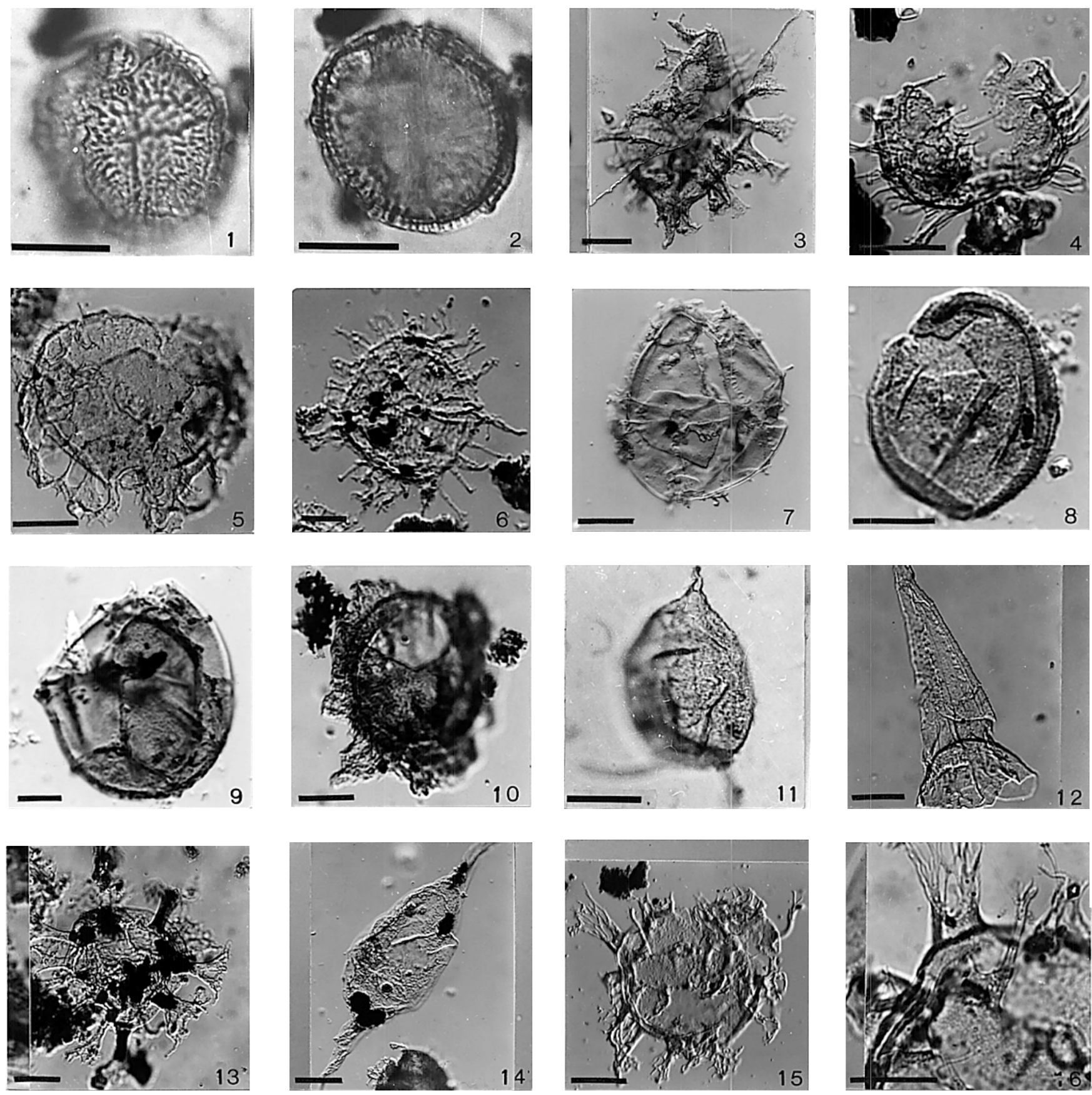

Plate 2. Photomicrographs of dinoflagellate cysts. Scale bar $=20 \mu \mathrm{m}$. 1, 2. Fibradinium annetorpense, length $42 \mu \mathrm{m}$, Sample 159-959D-46R-1, 95-100 cm, $842.25 \mathrm{mbsf}$, slide 2: G 34-2, (1) focus on the dorsal face, (2) optical section. 3. Fibrocysta axialis, length $112 \mu \mathrm{m}$, Sample 159-959D-48R-3, 65-68 cm, 864.25 mbsf, slide 1: H 30, general view. 4. Florentinia resex, length $52 \mu \mathrm{m}$, Sample 159-959D-67R-2, 57-61 cm, 1045.37 mbsf, slide 2: H 36, optical section, broken specimen. 5. Glaphyrocysta wilsonii, length $76 \mu \mathrm{m}$, Sample 159-959D-51R-4, 8-11 cm, 893.78 mbsf, slide 1: MN 24; general view. 6. Hystrichodinium cf. ramoides, central body length $68 \mu \mathrm{m}$, Sample 159-959D-62R-1, 76-78 cm, $996.16 \mathrm{mbsf}$, slide 2: M 48-49, focus on bifid or trifid distal ends of processes. 7. Impagidinium celineae, length $72 \mu \mathrm{m}$, Sample 159-959D-48R-3, 65-68 cm, 864.25 mbsf, slide 1: WX 34, dorsal face, exterior view. 8. Kallosphaeridium yorubaense, length $56 \mu \mathrm{m}$, Sample159-959D-45R-1, 34-39 cm, $831.94 \mathrm{mbsf}$, slide 3: S 28, general view. 9. Kenleyia pachycerata, length 112 $\mu \mathrm{m}$, Sample 159-959D-45R-1,34-39 cm, 831.94 mbsf, slide 3: J 25-26, lateral view. 10. Kenleyia lophophora, length 80 $\mu$ m, Sample 159-959D-52R-3, 10$13 \mathrm{~cm}, 901.90 \mathrm{mbsf}$, slide 1: M 25, focus on the antapical process and precingular archeopyle. 11. Liesbergia abdounensis, length 55 $\mu \mathrm{m}$, Sample 159-959D47R-1, 79-82 cm, 851.69 mbsf, slide 2: X 41-3. 12. Odontochitina porifera, length $112 \mu \mathrm{m}$, Sample 159-959D-58R-3, 93-96 cm, 960.03 mbsf, slide 3: F 34, operculum. 13. Oligosphaeridium pulcherrimum, total length $100 \mu \mathrm{m}$, Sample 159-959D-64R-1, 92-95 cm, 1015.62 mbsf, slide 2: FG 28-29, general view. 14. Palaeocystodinium australinum, length $156 \mu \mathrm{m}$, Sample 159-959D-57R-4, 114-117 cm, 952.74 mbsf, slide 1: Z 40, optical section. 15, 16. Perisseiasphaeridium pannosum, total diameter $96 \mu \mathrm{m}$, Sample 159-959D-44R-6, 60-62 cm, $828.70 \mathrm{mbsf}$, slide 2: EF 50, (15) general view, (16) detail of process. 

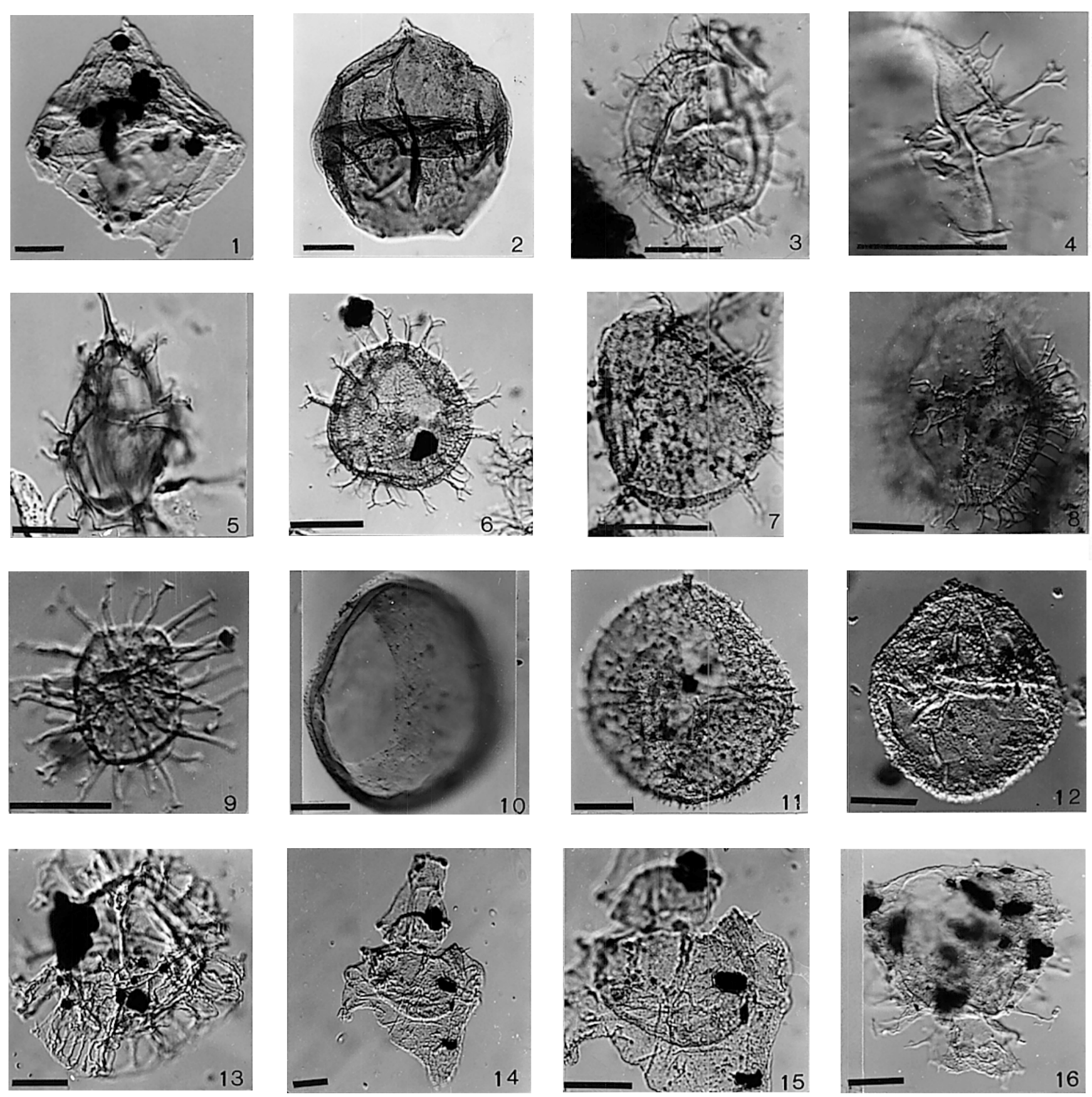

Plate 3. Photomicrographs of dinoflagellate cysts. Scale bar $=20 \mu \mathrm{m}$. 1. Phelodinium magnificum, length $104 \mu \mathrm{m}$, Sample 159-959D-60R-4, 16-19 cm, 980.76 mbsf, slide 2: J 42, general view. 2. Senegalinium laevigatum, length $80 \mu \mathrm{m}$, Sample 159-959D-58R-3, 93-96 cm, $960.03 \mathrm{mbsf}$, slide 3: 045, optical section. 3, 4. Spiniferites bejuii $\mathrm{n}$. sp., holotype, length $64 \mu \mathrm{m}$, Sample 159-959D-65R-2, 27-30 cm, $1025.87 \mathrm{mbsf}$, slide 1: F 34, (3) general view, (4) detail of the bridge-like structure of the septa (high to $5 \mu \mathrm{m}$ ). 5. Spiniferites cornutus ssp. cornutus, length $76 \mu \mathrm{m}$, Sample 59, 959D-45R-1, 34-39 cm, 831.94 mbsf, slide 3: Q 46, focus on apical process. 6. Spiniferites fluens, length $56 \mu \mathrm{m}$, Sample 159-959D-48R-3, 65-68 cm, 864.25 mbsf, slide 1: M 26-27, dorsal face, focus on processes. 7. Spiniferites hyalospinosus, length $52 \mu \mathrm{m}$, Sample 159-959D-44R-6, 60-62 cm, 828.70 mbsf, slide 1: S 48-4, optical section. 8. Spiniferites sp.G, length $76 \mu \mathrm{m}$, Sample 159-959D-66R-3, 40-43 cm, $1037.10 \mathrm{mbsf}$, slide 1: VW 47-48, focus on parasutural septa. 9. Tanyosphaeridium xanthiopyxides, total diameter $48 \mu \mathrm{m}$, Sample 159-959D-48R-3, 65-68 cm, 864.25 mbsf, slide 1: M 32-33, folded specimen. 10. Tectatodinium rugulatum, length $81 \mu \mathrm{m}$, Sample 159-959D-47R-1, 35-37 cm, 851.25m, slide 1: H 46, general view. 11. Trichodinium castanea subsp. bifidum, length $80 \mu \mathrm{m}$, Sample 159-959D-60R-4, 58-61 cm, 981.18 mbsf, slide 1: M 39-4, general view. 12. Trithyrodinium druggii, length 64 um, Sample 159-959D-56R-4, 60-62 cm, $942.50 \mathrm{mbsf}$, slide 1: J 43-4, central body alone, general view on opercule in place. 13. Unipontidinium grande, length 80 $\mu \mathrm{m}$, Sample 159-959D-64R-1, 92$95 \mathrm{~cm}, 1015.62 \mathrm{mbsf}$, slide 1: U 35-36, focus on parasutural septa. 14, 15. Xenascus ghanaensis $\mathrm{n}$. sp, holotype, total length 136 $\mu \mathrm{m}$, Sample 159-959D57R-2, 12-15 cm, 948.72 mbsf, slide 2: U 24, (14) general view, (15) detail on the large lateral coel. 16. Xenascus gochtii, length 80 $\mu \mathrm{m}$, Sample 159-959D66R-3, 40-43 cm, 1037.10 mbsf, slide 1: N 33-34, general view. 

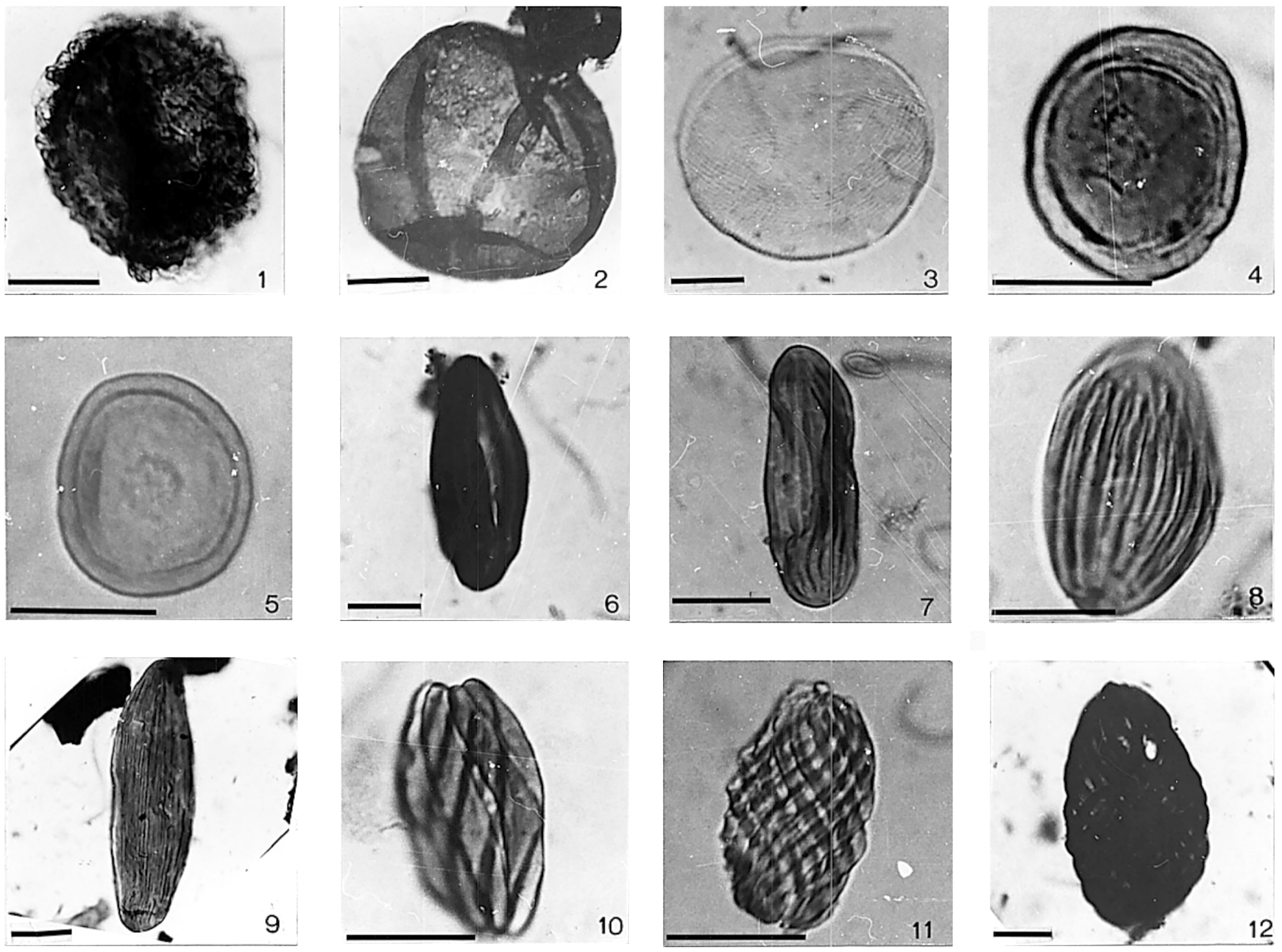

10
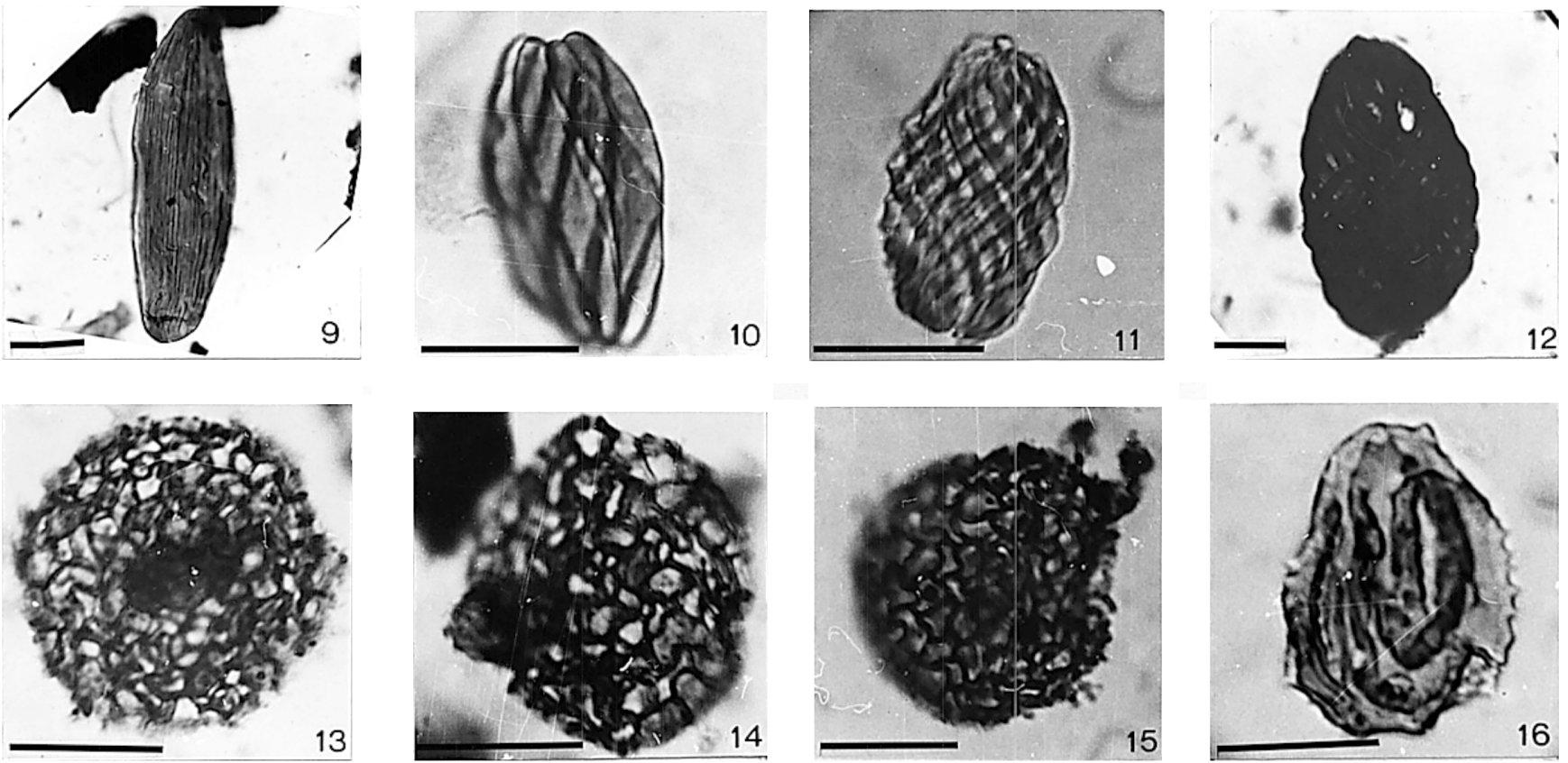

Plate 4. Photomicrographs of spores and pollen grains. Scale bar $=20 \mu \mathrm{m}$. 1. Crybelosporites pannuceus, diameter $55 \mu \mathrm{m}$, Sample 159-962B-9H-4, 65-70 cm, 79.15 mbsf, slide 2: M 40-41. 2. Araucariacites australis, diameter $65 \mu \mathrm{m}$, Sample 159-961A-35R-1, 3-6 cm, 308.23 mbsf, slide 1: Q 27-3. 3. Classopollis brasiliensis, diameter $68 \mu \mathrm{m}$, Sample 159-962B-9H-4, 65-70 cm, 79.15 mbsf, slide 2: D 47. 4. Classopollis sp., diameter $28 \mu \mathrm{m}$, Sample 159-962D20R-3, 8-14 cm, 261.48 mbsf, slide 1: Q 37. 5. Classopollis sp., diameter $29 \mu \mathrm{m}$, Sample 159-962B-9H-4, 65-70 cm, 79.15 mbsf, slide 1: GH 40-41. 6. Ephedripites ambonoides, length $62 \mu \mathrm{m}$, Sample 159-961B-10R-3, 117-122 cm, $317.37 \mathrm{mbsf}$, slide 2: U 28. 7. Ephedripites montanaensis, length $55 \mu \mathrm{m}$, Sample 159-962B-10H-4, 74-77 cm, 164.24 mbsf, slide 1: V 31-2. 8. Ephedripites zaklinskaiae, length $47 \mu \mathrm{m}$, Sample 159-962D-20R-3, 8-14 cm, 261.48 mbsf, slide 1: R 45. 9. Ephedripites sp. 7, length $123 \mu \mathrm{m}$, Sample 159-962D-20R-3, 8-14 cm, 261.48 mbsf, slide 1: Q 45-4. 10. Ephedripites sp. 8, length 39 $\mu \mathrm{m}$, Sample 159-962D-21R-2, 3-6 cm, 269.35 mbsf, slide 1: X 46. 11. Gnetaceaepollenites barghoornii, length 36 um, Sample 159-962D-9R-4, 65-70 cm, 79.15 mbsf, slide 2: P 31. 12. Gnetaceaepollenites jansonii, length $81 \mu \mathrm{m}$, Sample 159-961A-32R-1, 96-99 cm, 294.76 mbsf, slide 2: J 32. 13. Afropollis sp., diameter $42 \mu \mathrm{m}$, Sample 159-961B-9R-1, 15-18 cm, 303.65 mbsf, slide 2: L 46. 14. Afropollis sp., diameter 39 um, Sample 159-961A-34R-2, 82-87 $\mathrm{cm}, 305.82$ mbsf, slide 1: S44. 15. Afropollis sp., diameter $39 \mu \mathrm{m}$, Sample 159-961B-12R-1, 87-90 cm, 323.27 mbsf, slide 2: G 33. 16. Hexaporotricolpites emelianovi, diameter $33 \mu \mathrm{m}$, Sample 159-962D-27R-1, 40-44 cm, 311.70 mbsf, slide 2: W 30-2. 

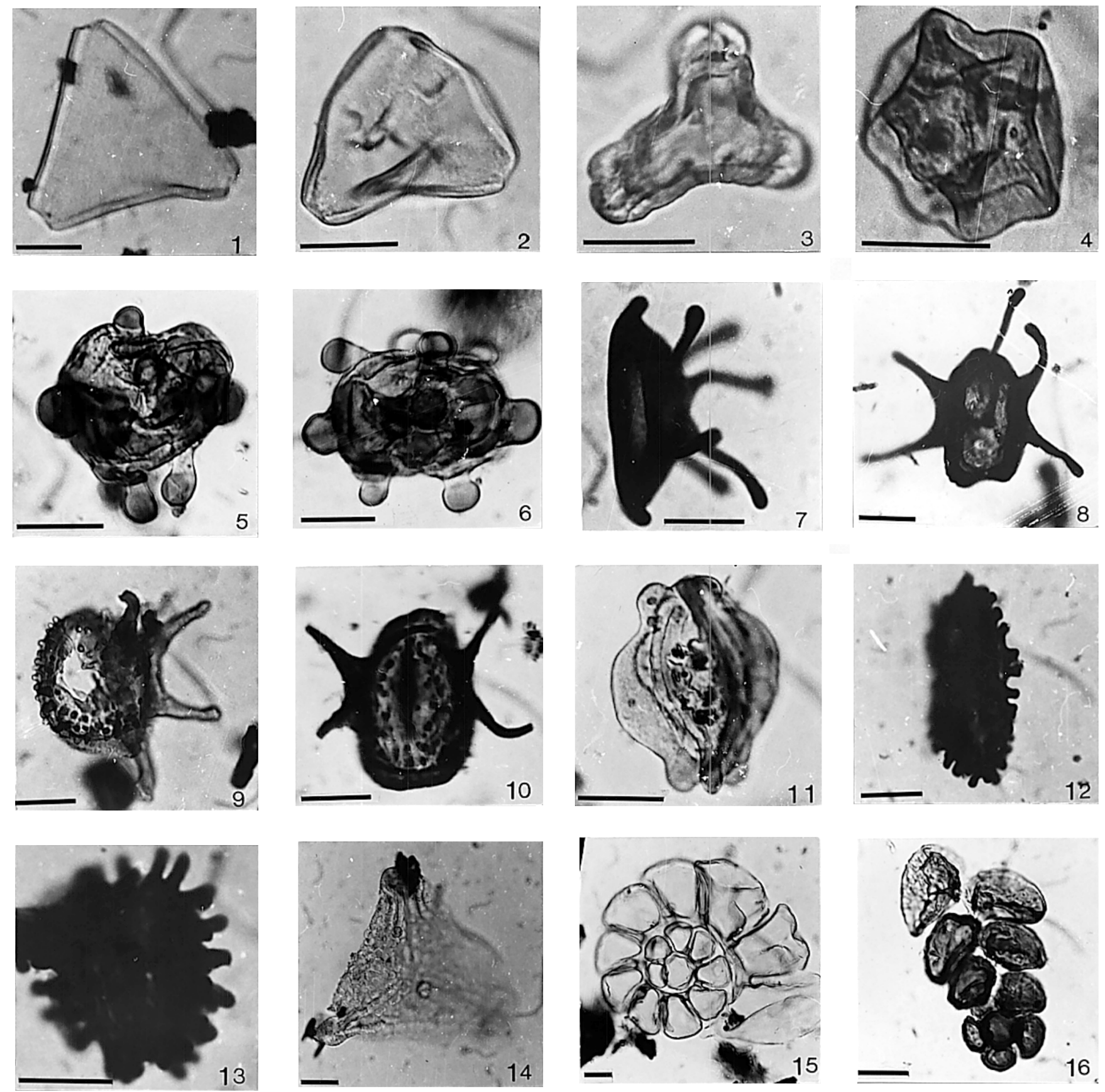

Plate 5. Photomicrographs of spores, pollen grains and foraminifers. Scale bar $=20 \mu \mathrm{m}$. 1. Triorites africaensis, height $52 \mu \mathrm{m}$, Sample $159-962 \mathrm{~B}-9 \mathrm{H}-4$, $65-$ $70 \mathrm{~cm}, 79.15$ mbsf, slide 2: K 55. 2. T. africaensis, height 39 um, Sample 159-962B-9H-4, 65-70 cm, 79.15 mbsf, slide 2: RS 41-42. 3. Triorites sp., height $33 \mu \mathrm{m}$, Sample 159-962B-9H-4, 65-70 cm, 79.15 mbsf, slide 1: T 50-3. 4. Cretacaeiporites sp., diameter $32 \mu \mathrm{m}$, Sample 159-962D-19R-2, 39-42 cm, 250.69 mbsf, slide 1: L M25 3-1. 5. Elaterocolpites castelaini, total diameter $49 \mu \mathrm{m}$, Sample 159-962D-29R-2, 37-40 cm, 327.87 mbsf, slide 1: E 45-3. 6. E. castelaini, total diameter $62 \mu \mathrm{m}$, Sample 159-962D-19R-2, 39-42 cm, $250.69 \mathrm{mbsf}$, slide 2: Y 44-4. 7. Elaterosporites klaszi, length without elaters 58 $\mu \mathrm{m}$, Sample 159-961B-13R-2, 26-28 cm, 333.86 mbsf, slide 1: R 38-4. 8. E. klaszi, length without elaters $48 \mu \mathrm{m}$, Sample 159-961A-34R-2, 82-87 cm, $305.82 \mathrm{mbsf}$, slide 1: S 30. 9. Elaterosporites protensus, length without elaters $48 \mu \mathrm{m}$, Sample 159-962D-30R-1, 40-42 cm, $336 \mathrm{mbsf}$, slide 1: T 36.10. Elaterosporites verrucatus, length $55 \mu \mathrm{m}$, Sample 159-961B-12R-1, 87-90 cm, $323.27 \mathrm{mbsf}$, slide 1: F 42-2. 11. Galeacornea causea, length $48 \mu \mathrm{m}$, Sample 159-962D-27R-1, 40-44 cm, 311.70 mbsf, slide 2: F 49 1-3. 12. Reyrea polymorphus, length $65 \mu \mathrm{m}$, Sample 159-961A-30R-2, 36-40 cm, 276.36 mbsf, slide 1: V 31-2. 13. cf. Reyrea, diameter $48 \mu \mathrm{m}$, Sample 159-961B-17R-1, 12-16 cm, $360.82 \mathrm{mbsf}$, slide 1: N 39-1. 14. Incertae sedis (trilete spore or syncolpate pollen grain), height $98 \mu \mathrm{m}$, Sample 159-962B-9H-4, 65-70 cm, $79.15 \mathrm{mbsf}$, slide 2: S 38-2. 15. Foraminifer, diameter 130 $\mu \mathrm{m}$, Sample 159-962D24R-2, 119-123 cm, 299.69 mbsf; slide 2: R 36. 16. Foraminifer, length $91 \mu \mathrm{m}$, Sample 159-962D-19R-2, 39-42 cm, 250.69 mbsf, slide 2: N $43-2$. 